مجلة جامعة الملك عبدالعنيز: الاقتصاد الإسلامي، م32 ع3، ص ص: 3-32 (محرم 1441/ أكتوبر 2019) DOI:10.4197/Islec.32-3.1

\title{
مراجعة في فقه الأسواق والهندسة المالية
}

\author{
عبدالجبارحمد عبيد السبهاني \\ قسم الاقتصياد والمصيارف الإسبلامية، كلية الشسرية \\ جامعة اليوموك، الأردن
}

المستخلص: مثَّلت الأسواق المالية إلى جانب المصارف التجاربة مؤسسات الوساطة المالية الأكثر أهمية في المجتمعات المختلفة. ويتعين على المجتمعات المسلمة بحكم إيمانها أن تلتزم في أسواقها المالية ومجمل

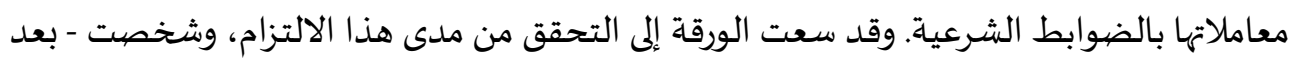

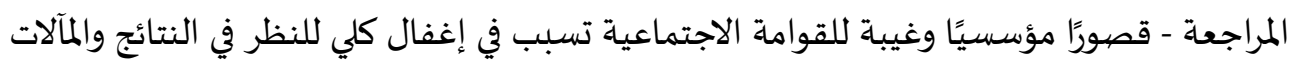

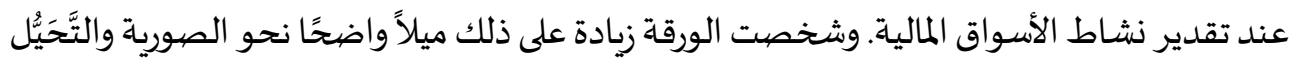

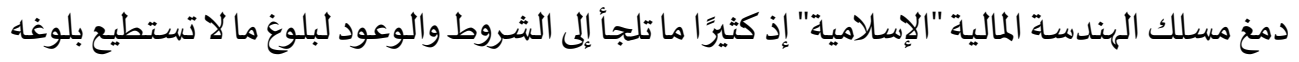
بالعقود. وختمت الورقة ببضع توصيات جاءت تعلية على الاستنتاجات الرئيسة التي خلصت إليها من

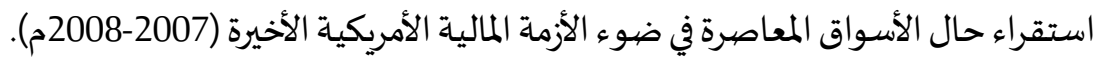
الكلمات الدَّالة: الأسواق المالية، الهندسة المالية الإسلامية، ضوابط المعاملات، الملكية النفعية، المضارباة.

\author{
تصنيف G190 ، G010 ، B590 :JEL \\ تصنيف C3, C59, K1:KAUJIE
}




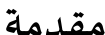

وظيفية النظام المالي الذي ينبغي أن يظل خادمًا للنشاط الحقيقي لا متشطرًا يبتز الاقتصاد الحقيقي ويتطفل عليه. وتهدف هذه الورقة بإجمال إلى بيان أبرز الضوابط التي

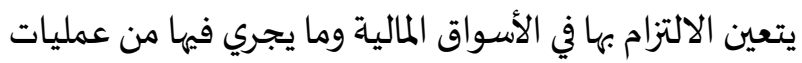
اكتتاب وتداول؛ لجهة مقاصد المتعاملين وبواعثهم، ولجهاة مباني العقود التي يعتمدونها في معاملاتهم، وبدرجة أكبر لجهة آثار أنشطة الأسواق المالية ومآلاتها على المجتمع والمصالح العامة، كما تهدف كذلك إلى مراجعة نهج الهندسة المالية ومعطياتها في الأسواق المالية الإسلامية.

وقد توزعت مادتها في فقرات تنتظمها ثلاث زمر الأولى في ماهية الأسواق المالية وأهميتها وأبرز أدوات السوق الإسلامية، والثانية في الضوابط الإجمالية لمشروعية المعاملات ذات الصلة بنوايا المتعاقدين وقصيودهم وبمباني العقود التمولية

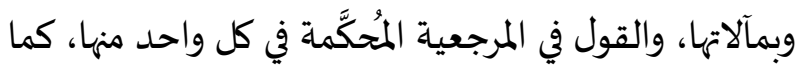
بحثت المضاربات(*) والموقف منها حكمًا وسياساة، أما الزمرة الثالثة فقد اهتمت بالهندسة المالية الإسلامية ومساراتها،

ومناهج تكييفها وهيكلتها للمنتجات المالية. (1)

\section{الأسـواق المالية وأدواتها الإسلامية}

\section{1-1 ماهية الأسواق المالية وتصنيفاتها}

السوق المالي: حيز عَقْدي يتم فيه التعامل على المال

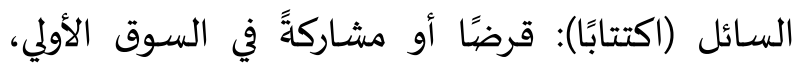

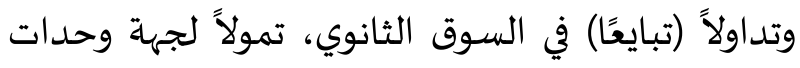
العجز، واستثمارًا لجهة وحدات الفائض، ومجازفة وتربصًا لجهة المتربحين من فروق الأسعار (المضاربين - المجازفين).

(*)الأصوب المجازفات وهي التعبير الأدق للممارسات المتعلقة بالأعمال التي تدخل تحت مسىى (Speculation) الإنجليزي، وهو ما أشار إليه المؤلف [التحرير].
تتعدد زوايا النظر إلى المجتمع بتعدد الاعتبارات التي يهتم

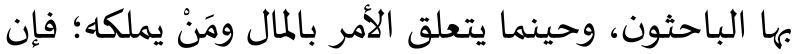

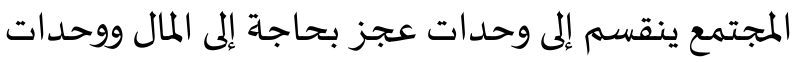
فائض لديها مال ترغب في تنميتاه. ومع نمو المجتمعات وتطورها غابت المواجهة المباشرة وغاب البعد الشخصي الذي كان يؤطِّر علاقة وحدات العجز بوحدات الفائض، وكان لا بد من وجود مؤسسات وسيطة تسهل حركة المال بين الفريقين؛ فكانت المصارف التجارية هي الجسر الذي يربط بين ضفتي المجتمع. وما لبث أن انضهم إلى هذا الجسر جسر آخر تمثل بالأسواق المالية. وقد مرَّت العلاقة بين بين

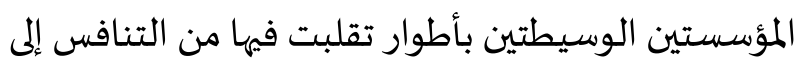
التعايش ثم إلى التخادم والتكامل. لقد مارست هاتان المؤسستان وظائفهما في الاقتصاد التقليدي مستندة إلى قناعة مذهبية مفادها "أن العقد

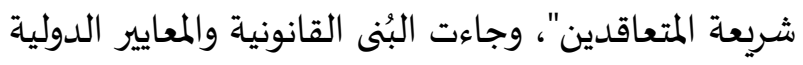
الناظمة لنشاطهما تترجم ذلك وتؤكده. ومع نشأة المصارف لماءل والأسواق المالية الإسلامية؛ كان لا بد من إدخال قيد على

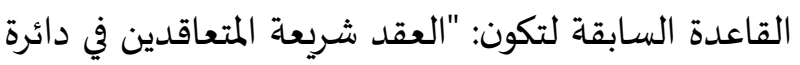
الإباحة"؛ إذ الرضا بذاته لا ينشئ مشروعية، ومراعاة هذا القيد: العمل في دائرة الإباحة هي مسوّغِ وجود المؤسسات

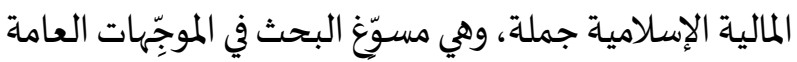

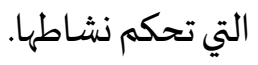

والإشكالات الرئيسة التي غطت مادة هذه الورقة تتمثل في الصورية التي جنحت إليها كثير من المعاملات المالية، والاحتيال الذي جنحت إليه مناهج الكثير من المعنيين بها، وفي

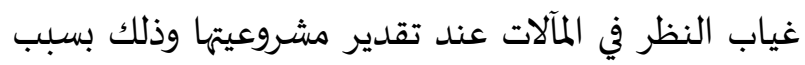
غياب السياسة الشرعية أو سلبيتها وما يجر إلياء ذلك من إهدار للمصالح العامة، وقد اهتمت الورقة أيضًا بتأكيد 
هذه السوق: البورصة، والسوق القارَّة، وسوق المزاد، والسوق الرسمي)، والسوق غير المنظمة يجري التعامل فهها عبر

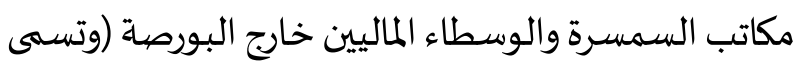
أيضًا السوق الموازية والسوق غير الرسمية).

\section{2-1: العلاقة بين المصارف التجارية والأسواق المالية} مرت العلاقة بين المصارف والأسواق المالية بعدة مراحل

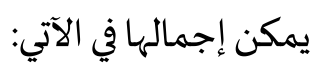

(1) مرحلة التنافس: كانت المصيارف التجارية تضططلع

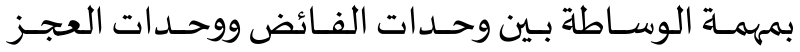
وتتكسب من فارق فائدة الاقتراض والإقراض؛ فلما ظهرت الأسواق المالية أصبح بإمكان المتمول أن يُصيدِر (أو تُصدَرَ

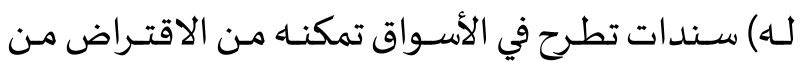

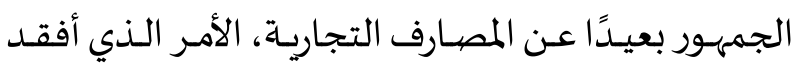

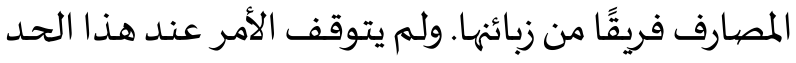

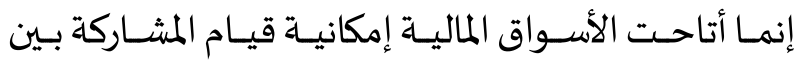
الممـولين والمتمولين وعلى نطاق واسع عبر إصـدار الأسههم. وهكذا دخلت السندات ضَرَّة للقروض المصرفية، ودخلت المشاركة ضَرَّة للمداينة جمملة.

(2) مرحلة التعايش: بعمليتها المعهودة وجدت المصارف التجارية أن من مصلحتها أن تتعايش مع الأسواق المالية فتحرز ما تستطيع إحرازه من سوق المال باستقبال عملاهها التقليديين من جهة، والتوثب لتقديم خدماتها المأجورة

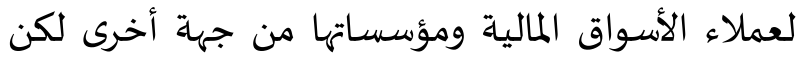
تحت سقف متدن من المخاطرة إذ ألزمتها التشريعات

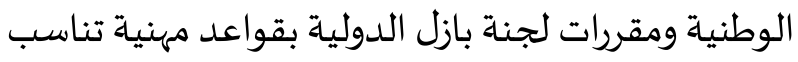
الوساطة المالية القائمة على أساس المداينة، وقد مثَّل تشريع (غلاس-ستيغال) (Glass-Steagall) في الولايات المتحدة الذي ظلَّ معمولاً بهاه حتى خواتيم القرن الماضي

$$
\text { روح هذه المرحلة. }
$$

وواضح من التعريف المتقدم أن السوق مؤسسة وسيطة تتيح لمن يطلب المال ولمن يعرضها التواصل الذي تتفاعل معاه إرادة المتعاملين ضمن إطار من المعرفة الضرورية المفترضة لاتخاذ قراراتهم المتعلقة بالمال. وللأسواق تصنيفات كثيرة منها: 1. تصنف الأسواق المالية على أساس العلاقات العقدية الرئيسة إلى سوق أولي تصدر فيه الأوراق المالية (الأسهم والسندات) التي يكتتب الممولون بها، وسوق ثانوي يتم فيه تداول تلك الأوراق التي سبق أن صددرت في السوق الأولي، وواضح أن السوق الأولي يحشد الموارد للاستثمار بينما يؤمِن السوق الثانوي السيولة لمن يرغب فيها ممن يملك الأوراق المالية، وصار هذا السوق تاليًا ميدانًا للمجازفين المتربصين ممن يتعقب فروق أسعار الأوراق المالية بعيدًا عن مقاصد الفريقين السابقين.

2. تصنف الأسواق المالية على أساس آجال التعامل إلى سوق النقد يتم التعامل فيه على السيولة لآجال قصيرة لا تتعدى السنة بالاقتراض المباشر أو عبر أدوات قصيرة الأجل مثل أذونات الخزبنة وشهادات الإيداع والأوراق

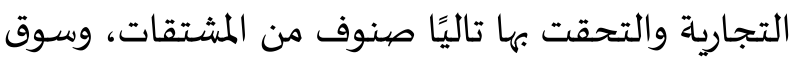

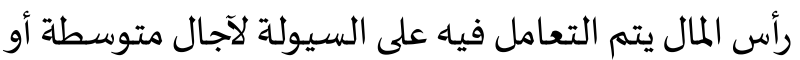

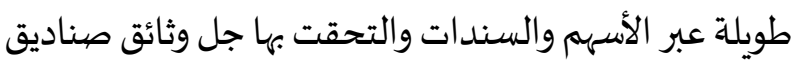

$$
\text { الاستثمار والصكوك الاستثمارية. }
$$

3. تصنف الأسواق المالية على أساس طبيعة الأصهول إلى

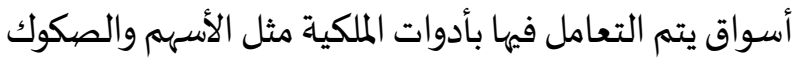
ووثائق صناديق الاستثمار، وأسواق يتم التعامل فهيا بأدوات المديونية مثل السندات والأوراق التجارية وشهادات الإيداع

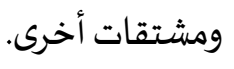

4. تصنف الأسواق المالية على أساس طريقة التعامل إلى سوق منظمة معلومة الموقع والأجل والإجراءات (ومن أسماء 
المالية وبخاصة قصيرة الأجل، ومنظمة إداريًا وتشريعيًا

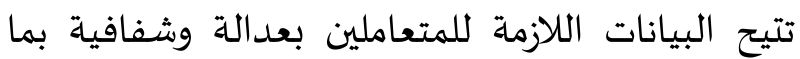
يخفض كلفة إجراء المعاملات ويختزل الوقت اللازم لذلك، وبما يحمي المتعاملين من التفرير والتدليس. والحق أن المصيارف الإسلامية تفتقر إلى هذه السوق

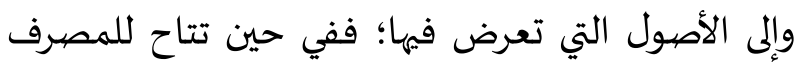
التقليدي الكثير من الأدوات التي يعتمدها في إدارة السيولة السيات

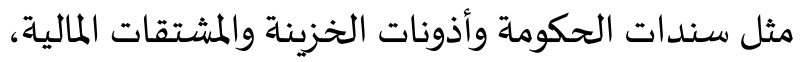
لا يتاح للمصارف الإسلامية شيء من ذلك؛ فكل هذه الأدوات تقوم على المداينة البرية وتداولها، ولذلك توالت الدعوات

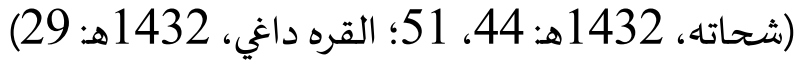

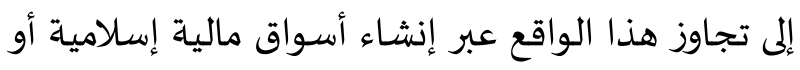
استحداث أقسام إسلامية في أسواقها المالية، وإنتاج أدوات مالية إسلامية قابلة للتداول والتسييل (زيتوني وناصر، 2012م: 145) وكانت ماليزيا رائدة في هذا

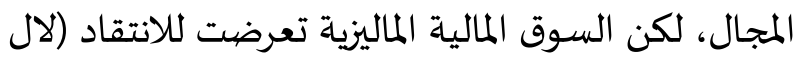
الدين وبو هراوة، 1432هـ 18؛ القطان، 2004م: 26؛ العياشي، 2015م: 42) لقيام جانب من أنشطتها على

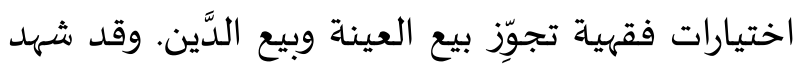

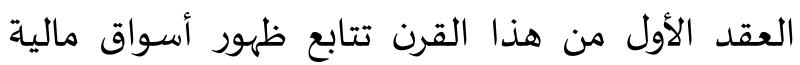
ومؤسسات متخصصية تبنت تيسير إدارة السيولة هدفًا

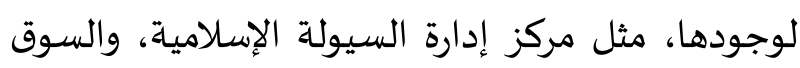

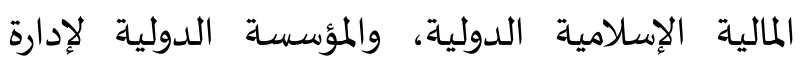
السيولة الإسالامية.

4-1 أبرز أدوات السوق المالية الاسلامية

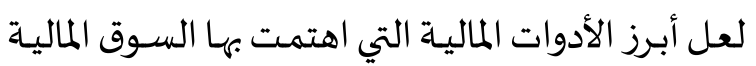

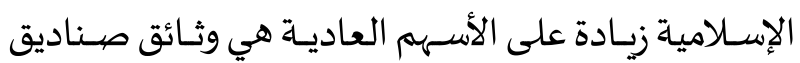
الاستثمار، والصكوك الاستثمارية. 1-4-1 وثائق صيناديق الاستثمار الإسلامية
(3) مرحلة الاندماج: أتاح إلغاء تشريع (غيلاس- ستيغال) للمصارف التجارية في أجواء المناخ الأيديولوجي الجديد التحلل من قواعد المهنة المصرفية التقليدية، والانخراط فيما عرف بالصيرفة الشاملة والمضاربات المالية والتعامل بسقف عالٍٍ من المخاطرة بعيدًا عن قواعد العمل المصرفي وصل حد التهور كما حصل للمصارف التي تهاوت مع بواكير الأزمة المالية في العقد الأول من هذا القرن. وقد أنتج هذا المناخ الأيديولوجي والواقع التشريعي الموقِّر للأسواق المالية

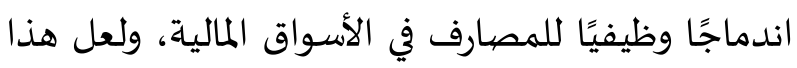
الواقع الجديد ومسؤوليته عن الأزمة المالية هو الذي بعث الحديث من جديد عن ضرورة إعادة تفعيل التشريع

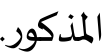

\section{3-1 أهمية الأسـواق المالية الإسلامية وضرورتها} لا شك أن وجود المؤسسة الوسيطة بين وحدات الفائض المسات المسله ووحدات العجز مطلب مُلِّح في المجتمعات المدنية المعاصرة حيث يغيب البعد الشخصي لصالح التنظيم المؤسسي، وإذا كانت الأسواق المالية المعاصرة تغرق في بحور من

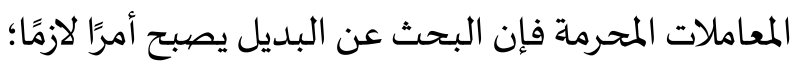
فالمتمولون والممولون بحاجة إلى السوق التي تؤمِّن لهم التواصل المثمر؛ هم بحاجة إلى إطار مؤسسي وإلى بنية تشريعية وإلى منظومة أدوات تحقق للطرفين مقاصدهما، بل وتحقق للسوق والعاملين فيها التكسب من هذه الوساطة المالية.

وبالمقابل تجد المصارف الإسلامية نفسها بحاجة إلى السوق المالي إذ إن كفاءة إدارة السيولة المصرفية تستلزم

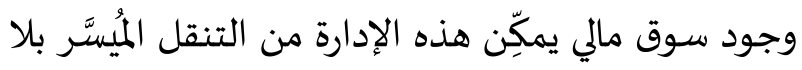

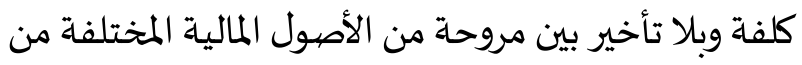

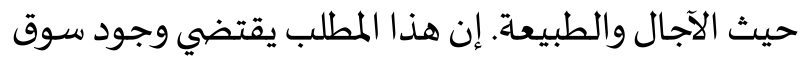
مالية خصببة تعرض بدائل كافية من الأدوات والأصيول 
1-1-4-1 الاستردادوالتداول:

صممت صيناديق الاستثمار المفتوحة على نحو يحقق

رغبة المستثمرين في السيولة عند الحاجة إلهها عن طريق

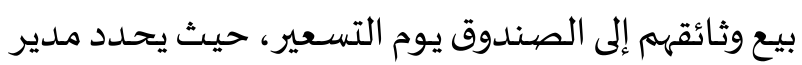
الصندوق يومًا معينًا من الشهر يسـى يوم التسعير. وفي

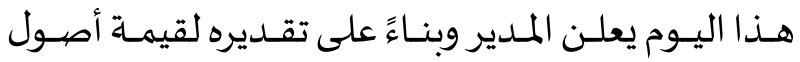

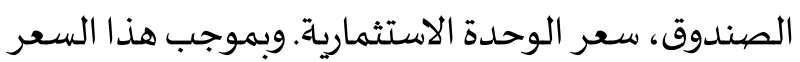

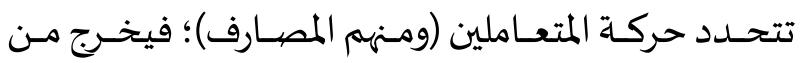

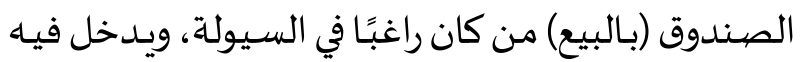

من كان راغبًا في الاستثمار.

أما الصناديق المفلقة فتحقق مطلب السيولة بإتاحـة

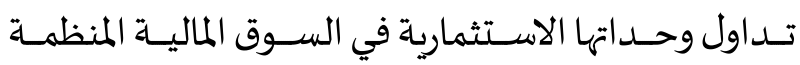
(البورصـة). وفي كل الأحسوال تنبغي مراعاة ما تمثله وثائق

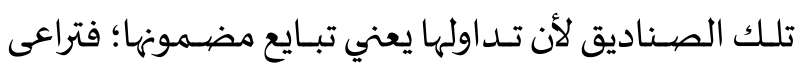

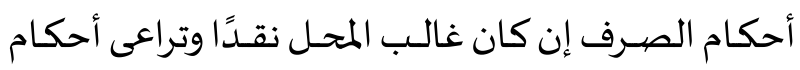
الدَّينْ إن كان غالب المحل دينًا.

\section{2-4-1}

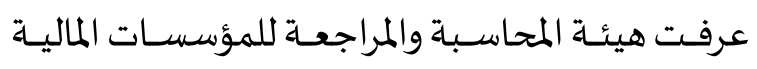
الإسلامية في معيارها الشرعي رقم (17) صكوك الاستثمار

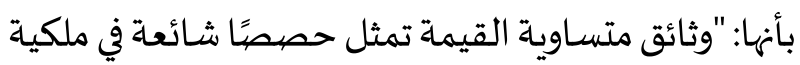
أعيان أو منافع أو خدمات أو في موجودات مشروع معين أو

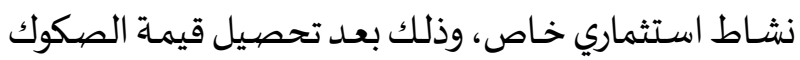

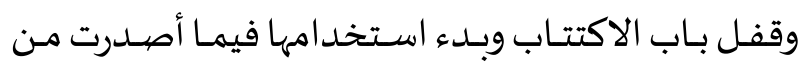

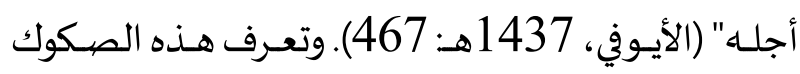
بالصكوك الاستثمارية تمييزًا لها عن الأسهم وعن سندات الهرف الهدهات

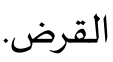

لا تختلف صناديق الاستثمار الإسلامية عن الصناديق التقليدية إلا بالتزامها بالضوابط الشرعية عند اختيار منظومتها العقدية ومجال نشاطها، فهي أوعية استثمارية

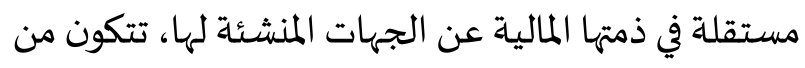
مساهمات مالية في صورة أسهم أو وحدات متساوية تمثل

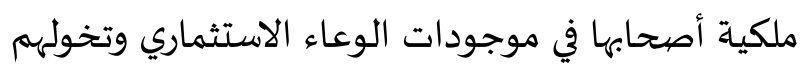
استحقاق ريح الاستثمار وترتب عليهم تحمل خسارته. وتدار هذه الصناديق على أساس المضاربة أو الوكالة هيئة الماتئة المحاسبة والمراجعة المالية للمؤسسات الإسلامية (الأيوفي، 2000م: معيار المحاسبة رقم 14).

ومن يكتتب بوثائق الصندوق يكون مالكًا لجزء من رأس مال المضاربة، الذي تتعهد إدارته باستثماره في مشروعات

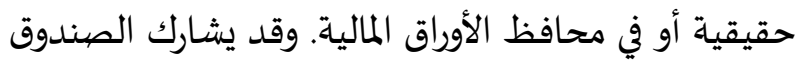

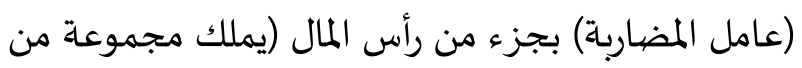

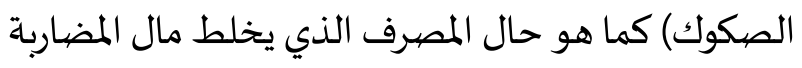
بماله ويعمل فيهما، وهنا تصبح العلاقة مع المضارب علاقة

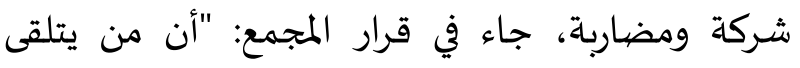

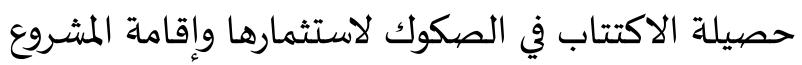

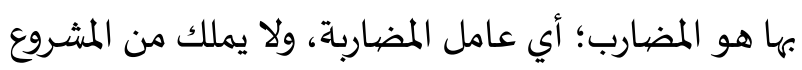

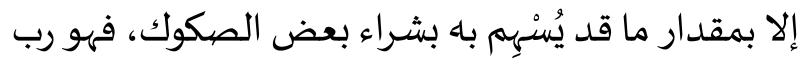

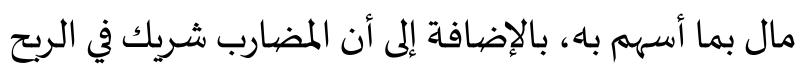

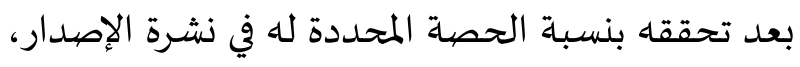

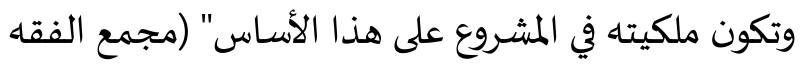

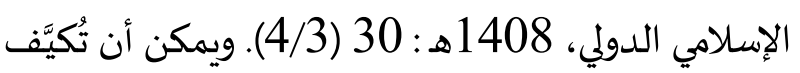
علاقة المستثمرين بالصندوق كشخصية اعتبارية مستقلة،

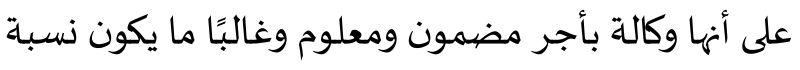
محددة من رأس المال. وهذا الاختيار يضيِّق الشُّقَّة بين

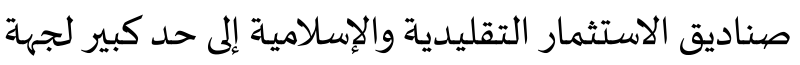

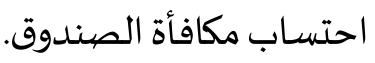


3. تُراعى أحكـام الــديون إذا تمــت التصــفية وكانـت

الموجودات ديونًا، أو تم بيع ما تمثله الصكوك بثمن مؤجل.

4. إذا كانت موجودات المشروع بعد قفل باب الاكتتاب

وتخصيص الصكوك وبدء النشاط، خليطًا من أعيان ومنافح ونقود وديون فالحكم للغالب؛ فإذا غلبت الأعيان

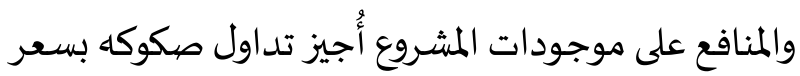

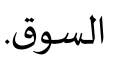

5. يجوز أن يَعِد مُصدِدر الصكوك في نشرة الإصدار،

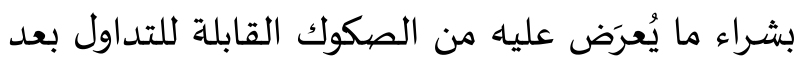

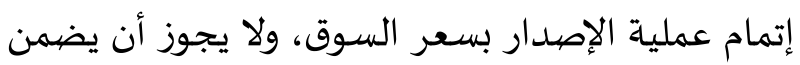

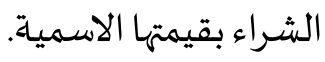

6. لا مانع من تداول الصكوك بكل الطرق المتاحة مثل التسليم أو القيد في السجلات الورقية والإلكترونية، طالما حققت انتقال الملك والقبض بوجه مشروع. ولا ينبغي الإصرار على أن يفضي التصكيك الإسلامي دومًا إلى إجازة التداول؛ فقد تقتضي سلامة المعاملات منعه كما في السَّلَم، وقد تقتضي المصالح الراجحة تقييده

$$
\text { منعًا للمضاربات المالية الضارة. }
$$

هذا؛ ولم تزل الصكوك تناضل لإثبات هويتها وعمليتها،

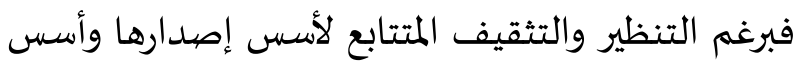

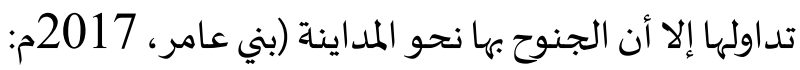
64) بتوقيت ملكيتها بالمخارجة المشروطة وتمييز هذه الملكية النفعية عن الملكية العدلية كان سيد الموقف من الناحية العملية (القري، 2014م: 18ـ 19)، كما لازمت المتكية الصكوك اختيارات تردد النظر الفقهي الجاد في قبولها مثل التبرع المشروط وضمان الطرف الثالث والوعد الملزم، يُزاد

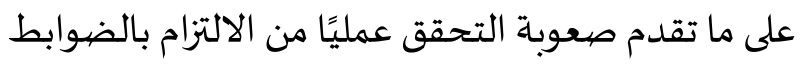

وجاء في قرار المجمع: "... أما التصكيك (التوريق الإسلامي) فهو إصدار وثائق أو شهادات مالية متساوية

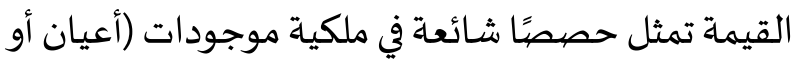
منافع أو حقوق أو خليط من الأعيان والمنافع والنقود والديون) قائمة فعلاً أو سيتم إنشاؤها من حصيلة الاكتتاب، وتصدر وفق عقد شرعي وتأخذ أحكامه" (مجمع الفقهاه الإسلامي الدولي، 1430هـ: قرار رقم: 178 (19/4). وإذًا فالتصكيك آلية لتقسيم قيم الموجودات إلى أجزاء متساوية، وإصدار صكوك ممثِلة لهذه الأجزاء وموثِّة لها، قابلة للتسييل بالتداول في الأسواق المالية؛ وتنجم عن عملية التصكيك هذه ولادة أدوات مالية جديدة هي

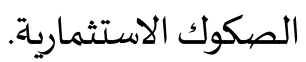

1-2-4-1 تداول الصكوك الاستثمارية الإسلامية يقصد بتداول الصكوك: تبايعها في الأسواق المالية.

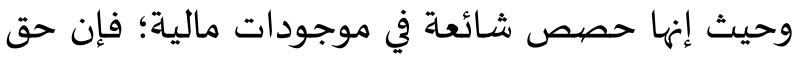

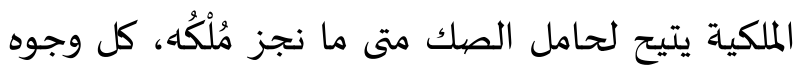
التصرف السائغة شرعًا مثل البيع والهبة والوقف والرهن، ووفق الضوابط الشرعية المتعلقة بكل صنف من صنوف المال التي تمثلها هذه الصكوك سواء أكان ذلك مع المُصدِدر أو مع غيره، ومما أشير إليه في هذا السياق (حسان، 2003م: 44؛ الأيوفي، 1437هـ أشير اليه في هذا 1479):

1. الأصل جواز تداول الصكوك إذا كانت تمثل حصة

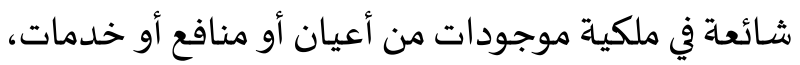
بعد قفل باب الاكتتاب وتخصيص الصكوك وبدء النشاط بحصيلتها. 2. تُراعى أحكام الصرف إذا كانت حصيلة الاكتتاب ما زالت نقودًا، فلا يباع الصك إلا بقيمته الاسمية دون زيادة إدان أو نقص. 
الإسلامية الاستفادة من المبتكرات المستمدة من أنظمة

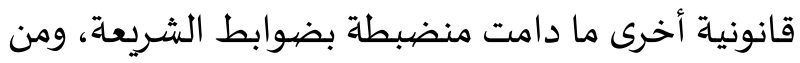

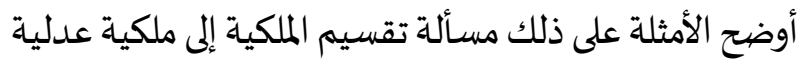
وملكية رسمية المستمد من النظام القانوني الإنجلوسكسوني المشتهر باسم قانون العموم وهذا التقسيم أضيحى عنصرًا أساسيًا في عدد من المعاملات المصرفية والمالية الإسلامية،

$$
\text { وبخاصة الصكوك" (القري، 2014م: 2، 7). }
$$

والحق أن إشكالات مبحث ملكية الصكوك لا يمكن اختزاله إلى مسألة اصطلاحية وخطأ في الترجمة كما بدأ من بحث القري حول تطبيق الملكية النفعية والملكية القانونية في التمويل الإسلامي الدولي، ولا في مسألة إجرائية حول تسجيل الملكية أو عدم تسجيلها كما يتضح من مرافعته الهاله

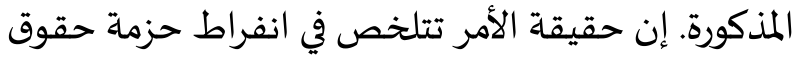
الملكية التي تثبت للمالك (حامل الصك) بفعل هيكلة

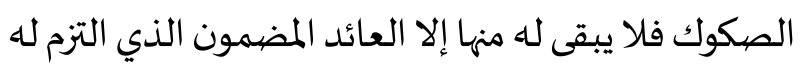

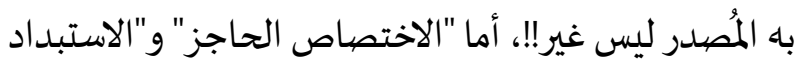
بالتصرف" و"أصالة تأبيد الملك واقتران الضمان به"؛ فكل الخاصن هذه المعالم الواضحة في النظر الشرعي قد اختفت مع إندان سُحُب الهندسة المالية.

3. يجب أن تتضمن وثائق الصكوك؛ الآليات اللازمة لضبط التطبيق والتأكد من خلوه من الحيل والصهورية ومعالجة الخلل المحتمل، والقيام بالمراجعة الدورية للتأكد من سلامة استخدام حصيلة الصكوك في الغرض المحدد لإصدارها، ومن تطبيق جميع مقتضيات العقود على الوجه

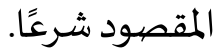

وهذه هي الأخرى توجيهات عامة لا تغني عن ضرورة تشخيص مواطن الحيل والصهورية في هندسة الصكوك بدقة ووضيوح.
الفقهية في التطبيق عند إصدار هذه الصكوك وعند تداولها (لال الدين وبوهراوة، 2010م: 28). وقد جاءت إتبات الضوابط العامة التي تضمنها قرار المجمع بشأن استكمال

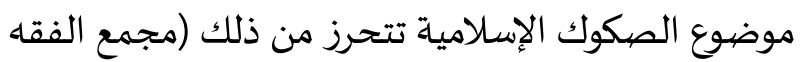
الإسلامي الدولي، 1433هـ: رقم 188 (3/20). وفيما

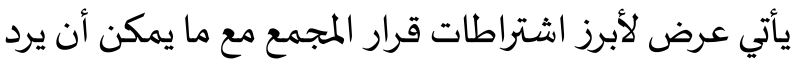

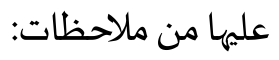
1. يجب أن تحقق الصكوك الإسلامية مقاصد التشريع من حيث: تعزيز التنمية ودعم النشاطات الحقيقية وإقامة

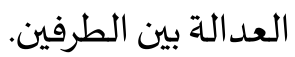

ومما يرد على هذه الناحية من قرار المجمع أن مقصيد تعزيز التنمية عنوان فضفاض لا يحتمل إناطة حكم شرعي به بالمنع أو الإباحة؛؛ فهل المقصود بهاه تنمية موارد

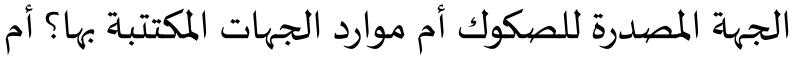
المقصود هو تنمية ناتج المجتمع الحقيقي؟. ثم إن إقامة العدل بين الطرفين هو الآخر عنوان عريض لا يحتمل

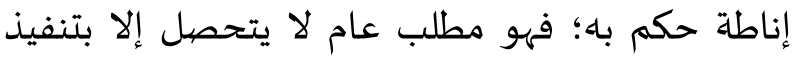
الأحكام التفصيلية في البيوع والعقود الإسلامية جملة. 2. يجب أن تحقق العقود الخاصة بالصكوك مقتضاها من حيث ثبوت الملكية شرعًا وقانونًا، وما يترتب علهيا من بن القدرة على التصرف وتحمل الضمان. والذي يرد هنا أن الهندسة المالية احتاطت لمثل هذا

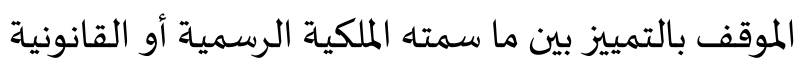
الظاهرة والملكية العدلية أو الحقيقية المستترة. ولما لم الم المعائ

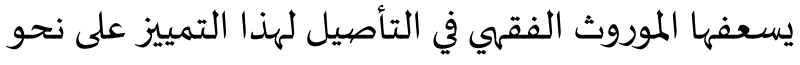

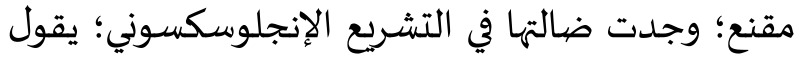

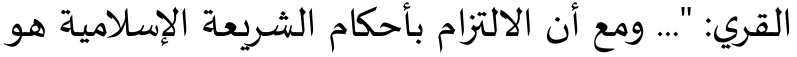

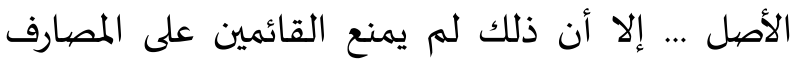


وعلى العموم فلا شك أن تنقية الصكوك الاستثمارية من العلل تتيح للمصارف الإسلامية وللمستثمرين المتعاملين في السوق مروحة واسعة من الأدوات المالية التي يمكن أن الن الماني تسهم مع وثائق صناديق الاستثمار في الحد من مشكلات

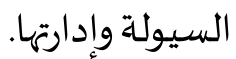

(2)

\section{الضيو ابط الإجمالية لمشروعية المعاملات المالية}

1-2 الضيو ابط الشرعية المتعلقة بالنو ايا والقصيود لا شك أن سلامة النية شرط لصحة المعاملة إذُ البواعث والنيّات أصل معتبر في مشروعية المعاملات لقول النبي

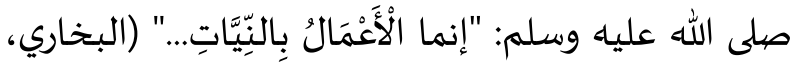
1407هـ، 1: 3)، وعلى هذا كانت القاعدة: "العبرة في

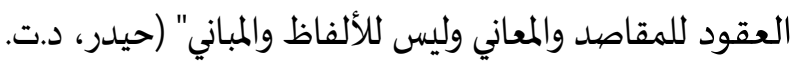
18:1). إن عموم الحيل المحرمة مثل بيع العينة ونكاح المحلل وهدية المتهرب من الصدقة ووصية المشرف على الموت عقود صحيحة المبنى لكن نوايا المكلفين وقصودهم منها لا تتطابق

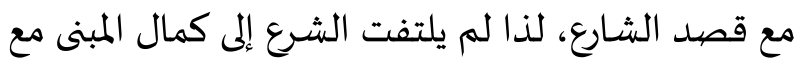
غياب الشرط الضروري للمشروعية وهو سلامة النية. ويمكننا أن نلاحظ في الأسواق المالية المعاصرة إغضاءً عن نية العملاء الذين يُطَوَّف بهم على نماذج من العقود تكتفي باستيفاء الإخراج الشكلي للمعاملات ولو كانت نوايا العاقدين المخالفة لمقاصد هذه المعاملات شاخصية ظاهرة

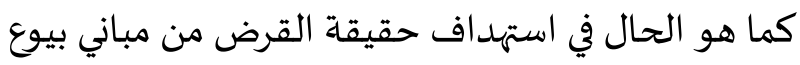

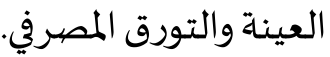

2-2 الضيو ابط المتعلقة بمباني العقود المالية

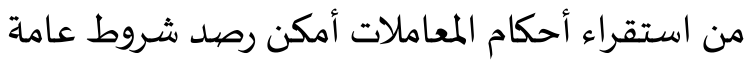
لسلامة مباني العقود المالية كما يأتي:
4. يجب أن تستوفي الصكوك الإسلامية الفروق الجوهرية بينها وبين السـندات الربوية من حيث الهيكلة والتصيميم

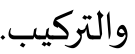

وهنا يلاحظ أن هندسة الصكوك لا تريد للمُلَّك (حملة الصكوك) أن ينفذوا إلى الأصول المصككة (القائمة منها أو الأصول التي ستقام بحصيلة التصكيك) لا بصفتهم مُلَّاكًا ولا بصفتهم دائنين عبر التنظير للملكية النفعية التي تقدم ذكرها، وعبر توسيط الشركة ذات الغرض الخاص، وقرار

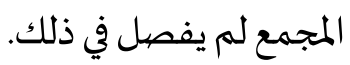

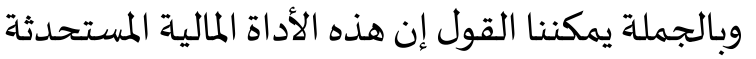
يتنازعها توجهان: الأول يريد لها أن تأخذ أبعادها الحقيقية

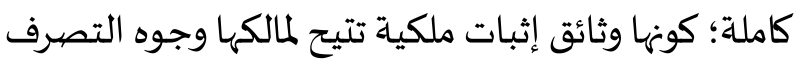
السائغة في محل العقد الذي صدرت هذه الصكوك بموجباه، والثاني يجنح بها نحو الصورية عبر رياضية عريضية تسعى إلى تفكيك حق الملكية وتوقيته استدرارًا للمغانم ودرءًا للمغارم؛ بتحريز الأصول من نفوذ تصرفات حملة

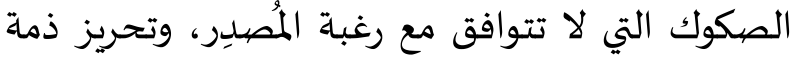

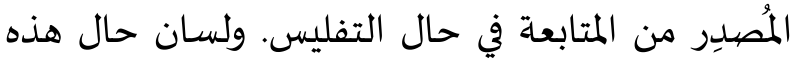
الرياضة يقول: لا لمخاطر الملك، ... لا لمخاطر الرهن، ... لا

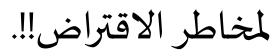
والذي يبدو أن هذا التوجه الممني تقف خلفه مصالح نافذة في الأسواق المالية المحلية والدولية سعت إلى تفعيل الاستثمار الدولي ومأسسة إدارة السيولة عبر الحدود، وأهنا

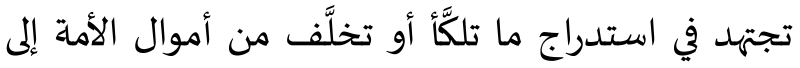
حيث تريد بواسطة الصكوك، وما فورة "التمويل الإسلامي

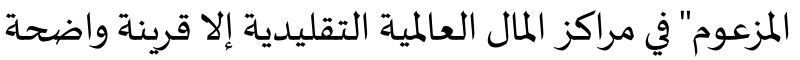
تكشف عن هذه الحقيقة. 


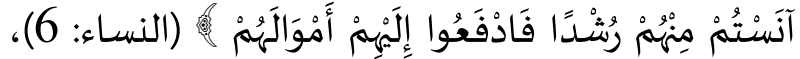
وللفقهاء تفصيل بصدد تصرفات الصبي لجهة تمييزه، ولجهاة إذن وليه، ولجهاة نفع هذه التصرفات أو ضررها. ثالثًا: أهلية العاقدين الحقوقية، كما تلزم الأهلية الحقوقية في المعاملات المالية، بأن يلي العقد (مالك) المال أو من ينوب عنه شرعًا (الكاساني، 1982م، 5: 148:

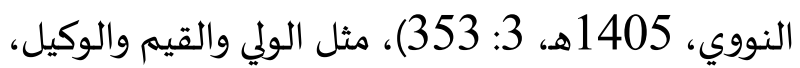
فلا يعتد بتصرف الغاصب والفضولي، إذ الإنسان مسلط على ماله بحكم الشرع ولا ينازع في ذلك. والشرع يشترط كذلك خلوص هذه الأهلية بانتفاء المانع من التصرف في في في

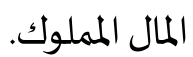

رابعًا: براءة محل العقد من الخبث ووجوب كونهاه مالاًا

متقومًا، وكل ما ليس كذلك فلا يجوز التعاقد عليه؛ فكل ما لم يبح الشارع استهلاكها لا يجوز بيعاه والانتفاع بثمنه،

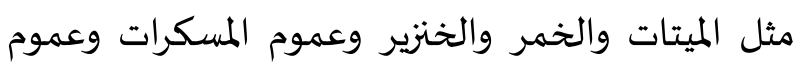
المخدرات ووسائل اللهو وأدواته، وكذا الحال في الإجارات، فلا بد أن تطيب الخدمة حتى يحل العقد عليها، وفي هذا السياق اشتهر النهي عن مهر البغيّ وحلوان الكاهن (ابن

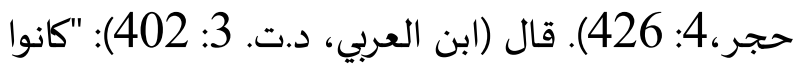
يأمرون ولائدهم فيباغين ...؛ فيأتيهم بكسبهن"، ونقل (القرطبي، 7: 3) عن ابن عبدالبر قوله: "من المكاسب المجتمع على تحريمها الربا ومهور البغايا والسحت والرشا الريا وأخذ الأجرة على النياحة والغناء وعلى الكهانة وادعاء الغيب وأخبار السماء وعلى الزمر واللعب والباطل كله". خامسًا: معلومية محل العقد علمًا ينتفي معه الغرر،

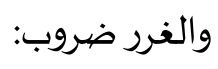

(أ) غرر الوجود، وفيه يتطرق الاحتمال بالوجود أو العدم إلى محل العقد، ومثال ذلك: بيع المضامين والملاقيح وحبل الحبلة؛ فهو عند الحنفية ما استوى (تكافأ) فيه
أولاً: رضا العاقدين في دائرة الإباحة الشرعية، والرضا

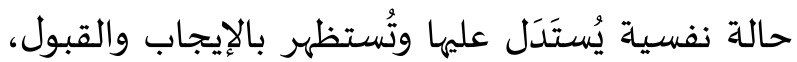
وكل منهما إرادة جادة جازمة مصرَّح بها متجهية لإبرام العقد، ويصح أن يعبر عن هذه الإرادة بكل ما دل على مقصودهما

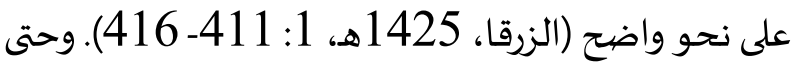
يتحقق الرضا لابد من براءة العقد من عيوب الإرادة؛

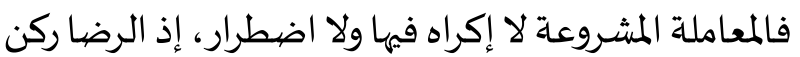

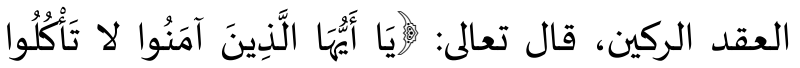

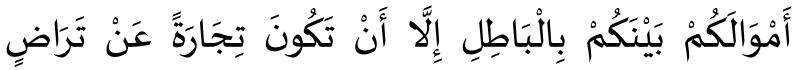

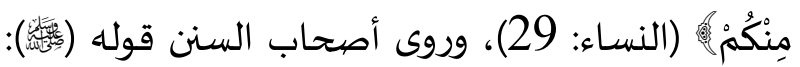

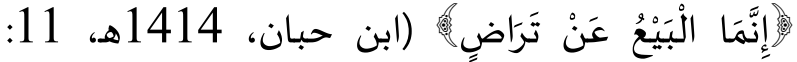
340)، وقوله: "لا يفترقن بِِّعان إلا عن رضا" (البهيهي،

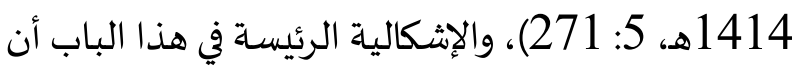
الوعد الملزم الذي أصبح من مقدمات العقود التمولية له اله

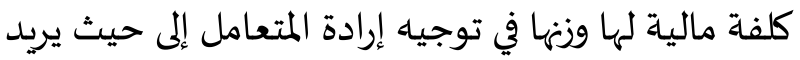
الطرف الآخر وهذا أمر يخل بالرضا لأنه يعيب الإرادة.

ثانيًا: أهلية العاقدين المعرفية، فيلزم في المعاملات

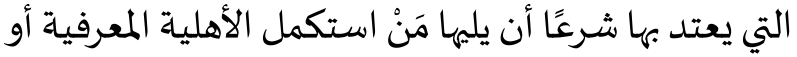

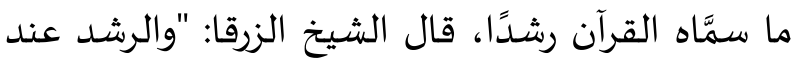
الفقهاء في هذا المقام ... ليس الورع والتقوى، بل هو التهان التران

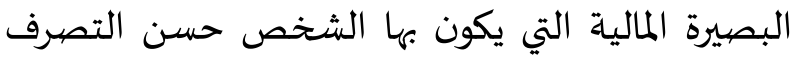
بالمال من الوجهة الدنيوية، ولو كان فاسقًا من الوجهة

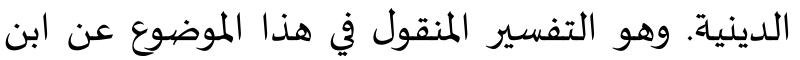
عباس" (مرجع سابق 2: 819)، ويعرف الرشد بالبلوغ والعقل، فلا يُعتدُ بتصرفات القاصر والمجنون والسفيه. والمجتمع المسلم مأمور بمنح من لا يملك الأهلية المعرفية

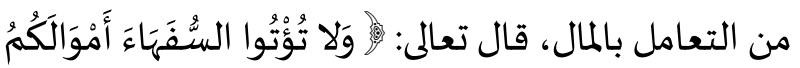

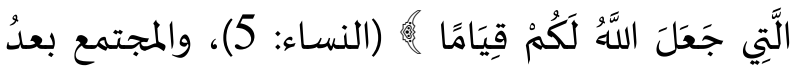

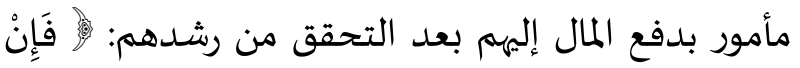


يخالطها، وهو ما أكدته الأحاديث التي نهت عن الغرر بمختلف صوره. سادسًا: السلامة من الربا، والربا علة منكرة سعت أحكام المعاملات إلى التحرز منها، وهو أبواب كثيرة هيهنا في

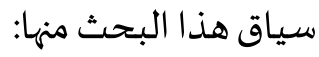

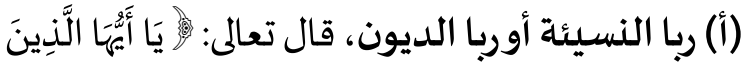

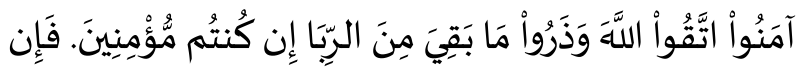

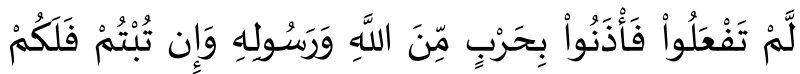

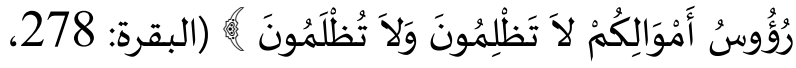
279)؛ وربا النسيئة هو الزيادة المشروطة لفظًا أو عرفًا على أصل ما ثبت في الذمة نظير التأجيل؛ وما يثبت في الذمة قد يكون ناتجًا عن قرض أو عن بيع مؤجل الثمن، أنمان

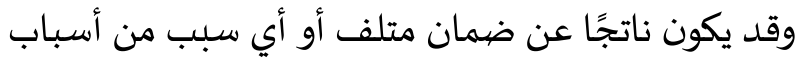

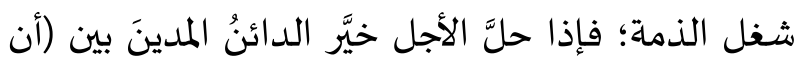
يقضي أو أن يربي) أي يسدد الدين أو يقبل جدولة الدئ الدين الدين بشروط الدائن؛ فيُمَّل ويُزاد عليه مبلغ الدين. وقد يكون من يطلب الجدولة هو المدين الذي يقول لدائنه: (أنظرني ... أزدك). وقد ينعقد القرض ربويًا ابتداء: أقرضك مائة

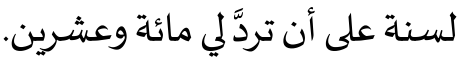

(ب) ربا البيوع، وله وجهان أولهما ربا الفضل: وهو الزيادة في مقدار أحد البدلين الربويين المتحدين جنسًا؛ فالإجماع منعقد على وجوب التماثل قدرًا عند مبادلتهما:

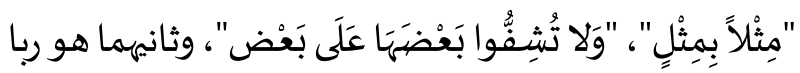

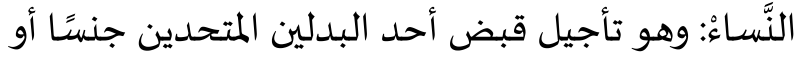

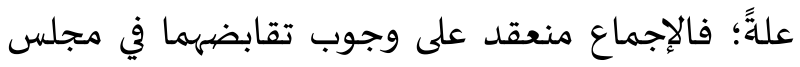

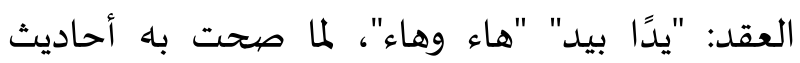
الربويات الستة على تفصيل للفقهاء بصدد استنباط علة

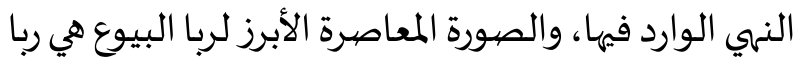

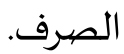

طرفا (احتمالا) الوجود والعدم (الكاساني، 5: 163)، وحقيقته عند المالكية: "التردد بين أمرين أحدهما على الى الى الماني،

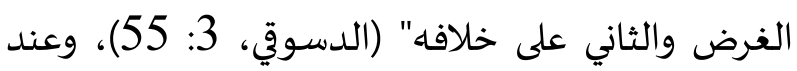

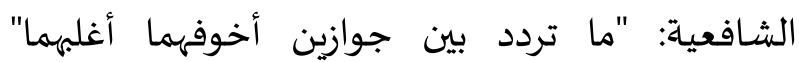
(الماوردي، 18: 147)، وعند الحنابلة: "ما تردد بين أمرين

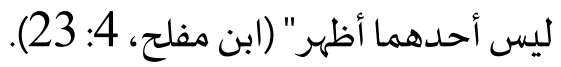
(ب) غرر الحدود أو الصفات، وفيه يتطرق الاحتمال

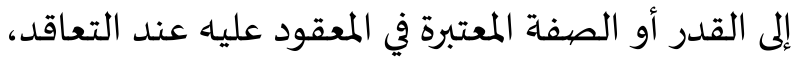

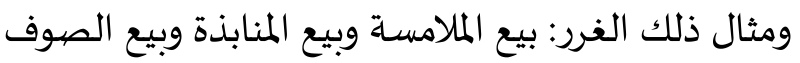

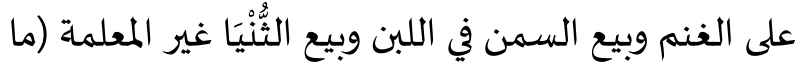
يستثنيه العاقد من محل العقد دون أن يعينه كقوله

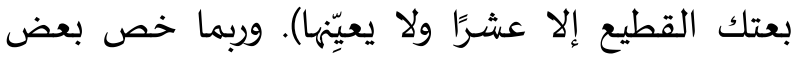
الفقهاء هذا النوع من الغرر بمصطلح الجهالة: ما علم حصوله وجهلت صفتها.

(ج) غرر التقبيض، وفيه يتطرق الاحتمال لا إلى وجود محل العقد ولا إلى صفته، إنما إلى إمكانية تقبيضيه وتسليمه، ومثال هذا الضرب من الغرر بيع السمك في الماء والطير في الهواء وبيع الحيوان الشارد. وكل هذا الكلام في

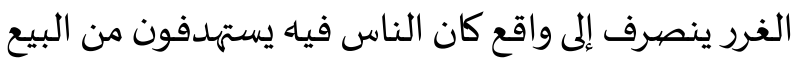
التملك والتمليك، أما السوق المالي اليوم فالأمر فيه

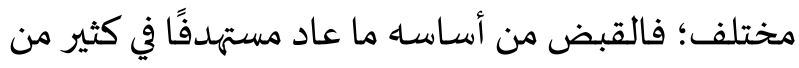

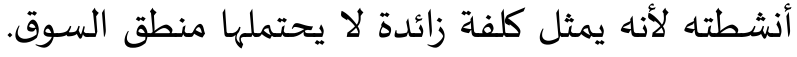
والمحل قد لا يهتم به العاقد فهو في كثير من العقود بمثابة حريرة التحليل كما في العينة والتورق. (د) غرر المواعيد أو الآجال، فيما كان تسمية الأجل شرط لصحته كما في السَّلَم. وواضح مما تقدم أنَّ الغرر علة معرفية تقدح بالعقود التي ينبغي أن تُرسى على أساس من المعرفة التامة؛ فهذه

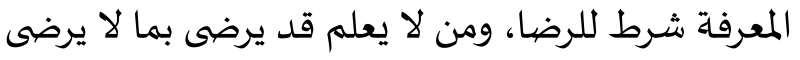
به حال علمه، ولذلك يطيح الغرر بمشروعية البيوع التي 
إلياء ذلك الفعل ... وهذا مجال للمجتهد صعب المورد إلا أنها

عذب المذاق محمود الغب جارٍ على مقاصد الشريعة". وإعمالاً للمنطق المتقدم يحكم بدفح الضيرر ولو لم ينو لمداف المتسبب فعله، ويستدفع الضرر العام بالضرر الخاص، ويُقدَّم دفع المفاسد على جلب المصالح، وكل هذا يترك القول الفصل فياء للقضاء وللسياسة الشرعية؛ فتقييد المباح أو منعاه هو المتعين شرعًا إذا آل المباح إلى ضرر أو

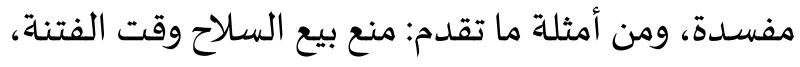
ومنع بيع العنب لمن يعصره خمرًا، وهو مسوغ ما ذهم اذهب إليه

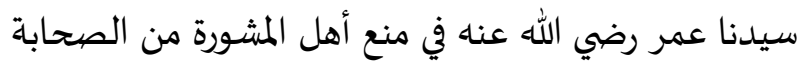
من مفارقتا إلى الأمصار، وفي منعحه زواج المسلمين من الكتابيات، واعتزامه تحديد المهور دفعًا لعقابيل المغالاة فيها. والخلاصة إذًا، أنه لا بد لمشروعية المعاملات المالية من: سلامة النية أولاً، ثم سلامة المبنى ثانيًا، ثم سلامة المآل ثالثًا.

\section{4-2: مَنْ المُحكَّم في سلامة النو ايا والمباني والمآلات؟} يبدو من الأهمية بمكان أن نشير إلى المرجعية المُحكَّمَة

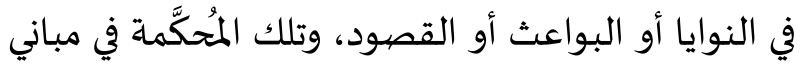

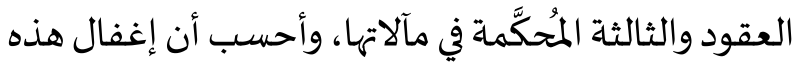
الحقيقة جر على الأمة بلاء كثيرًا، وأدخل المعاملات في غَبَش لا يسوغ قبوله. إن المكلف هو المحكَّمَ في نواياه وهو المَّه الأعرف ببواعثاء وقصيوده فلا يستفتي فيها غيره، ولا تغني

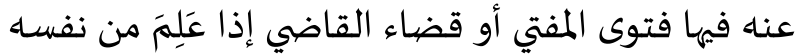

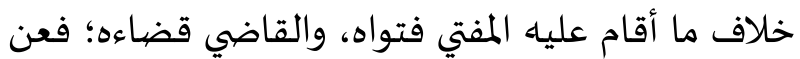

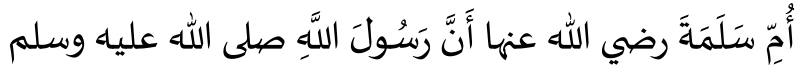

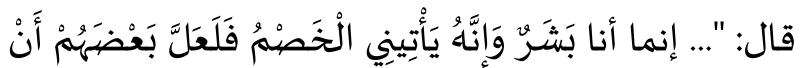

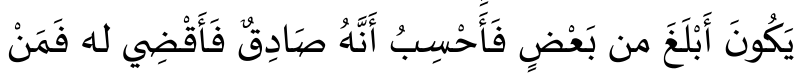

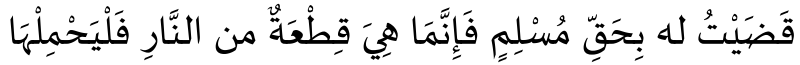
أو يَذَزْهَا" (مسلم، د.ت. 1337: 133 ). أما مباني العقود فيُستفتى فيها الفقيه بأحكام المعاملات المالية؛ فهو الأعرف بالعقد ومقوماته: ركناه ولوازمه وما يمكن
(ج) ربا الصرف، الصرف بيع مخصوص كلا عوضياه من جنس الأثمان، وربا الصرف هو زيادة قدر أحد البدلين مع اتحاد جنسهما (فضل)، أو تأجيل قبض أحدهما (نساء)؛ إذ يشترط لصحته شرطان: أولهما الحلول والتقابض الص مطلقًا، وثانيهما: وجوب التيقن من التماثل وزنًا عند اتحاد

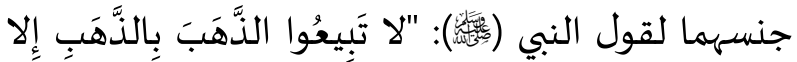

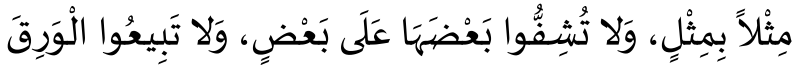

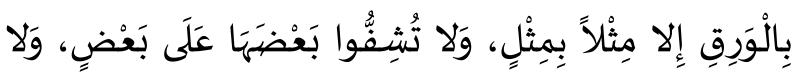

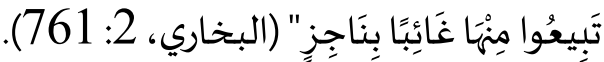
ولمِا تقدم؛ اشترط الفقهاء نفي الخيار والأجل في الصرف يطَّرد ذلك مع اتحاد الجنس ومع اختلافه، كما اشترطوا نفي الجهالة والجزاف إذ الجهل بالمماثلة كالعلم بالمفاضلة فلا يجوز (القفال، 1988م، 4: 191: 198 السمرقندي، 1984م، 3: 31). وواضح مما تقدم أن ربا الصرف صيورة لربا البيوع؛ وإنما أفرد ذكره لخطورة شأنها في الاقتصادات ولهات المعاصرة حيث انحسرت المقايضات، وعمَّ التعامل بالنقود وفي النقود. 3-2: الضيو ابط المتعلقة بسامة المآلات والنتائج لا يكفي أن تكون قصود المتعاملين وبواعثهم مشروعاة، وأن تكون مباني العقود صحيحة، لاكتمال المشروعية ونجوزها، إنما يلزم بعدُ النظر في مآل المعاملات ونتائجها؛ فإن آلت إلى مفسدة أو ضرر بيّن حُكِمِم بمنعها ولو كانت

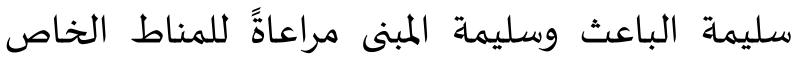
وتقديمًا له على المناط العام، قال (الشاطبي، د.ت. 4: 195): "النظر في مآلات الأفعال معتبر مقصود شرعًا... وذلك أن المجتهد لا يحكم على فعل من الأفعال الصادرة عن المكلفين بالإقدام أو الإحجام إلا بعد نظره إلى ما يؤول 
أما المآل فيُستفتى فيه طرفان:

1) القضاء؛ للنظر في الأضرار والمفاسد الخاصدة التي

قد تلحق بآحاد الناس من جراء تصرفات المكلف المالية ولو

لم يكن يقصهدها.

2) السياسة الشرعية التي تنظر في الأضيرار العامة أو

المفاسد التي تلحق بالمجتمع جراء التصرفات المالية للأفراد

والمؤسسات ولو كانت هذه التصرفات والأنشطة سليمة في

بواعثها وسليمة في مباني عقودها، والمتعين عندئذ الحكم

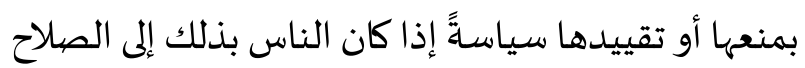

$$
\text { أقرب وعن الفساد أبعد. }
$$

والمشكلة المعضلة تكمن في أن السياسـة الشرعية تركت

الأسواق والمؤسسات المالية لفتاوى لجان الرقابة الخاصية

التي حصرت اهتمامها بمباني العقود واجتهدت في الذبِّ عن صحتها كما يفعل محامي الدفاع في المرافعات القضائياة، أما السياسة الشرعية التي تمثل المصلحة العامة (الادّعاء

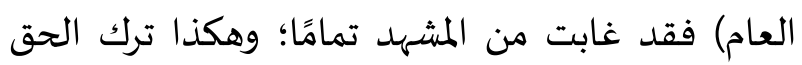

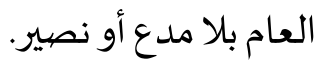

لقد أثثت الواقع أن إطلاق نشاط الأسواق والمؤسسات

المالية يترك ضررًا على الجمهور وعلى الاقتصاد الحقيقي؛

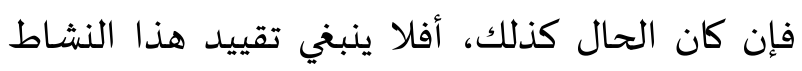
وتوجيها بما يدرأ ضرره؟! إن مما ينبغي أن تفهما لجان إنان

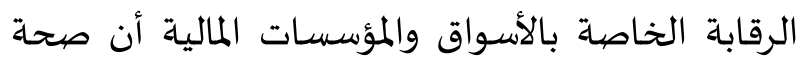

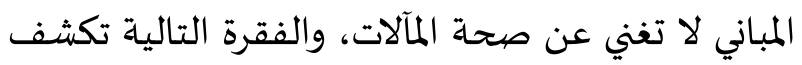

$$
\text { عن فداحة الخلل في مقاربة هذه المسألة. }
$$

5-2: تداول الأسهم بين الحكم الشرعي والسياسـة الشرعية

$$
\text { 1-5-2 تداول الأسههم فقهًا: }
$$

يقصيد بتداول الأسهم توالي (تعاقب) بيعها في سوق

الأوراق المالية. وحيث إن السهم حصية شائعة معلومة في
أن يخالطها من علل تطيح بمشروعية المعاملة بطلانًا أو 
وفي المضاربة أيضًا تحتل الاستخدامات قصيرة الأجل للموارد المالية المقام الأول على حساب الاستثمار الحقيقي،

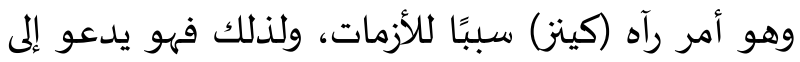
تحصين الاستثمار منها لتتحقق له الجدية والاستقرار فيقول: "إذا جعلت عمليات الاكتتاب (تملك الأسهم)

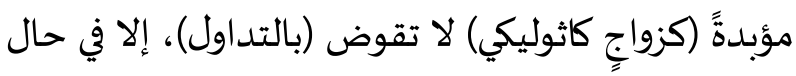
موت المساهم أو لأسباب قاهرة، فإن ذلك سيكون حصانة من الأزمات، لأنها يجبر المستثمرين على تركيز انتباههم على لمانى الفرص الاستثمارية طويلة الأجل" (Keynes,1973:160). والمطلوب إذًا، شركة دائمة تنطوي على استثمار حقيقي طويل الأجل، ويتحقق فيها انتماء المساهمين لشركاتهم، لا لا

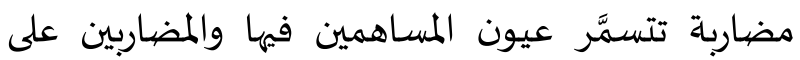
شاشات المصافق، وتجعل المساهم يتبرأ من أسهمها وشركائه عند أول سانحة مضاربية لجني الأرباح. إن الارتباط بين النشاط المضاربي والأزمات المالية

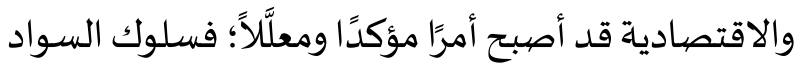
الأعظم من المتعاملين في السوق المالي كما يقول (كينز) يستند إلى استقراءات سطحية، ويكون عرضة لتحولات شديدة ومفاجئة ومتعاكسة، بسبب تبدل قناعاتهم وعدم رسوخها، مما يقود إلى زعزعاة النشاط الاقتصادي (Keynes,1973:154). ويشير (آليه، 1413هـ: 14) إلى الى

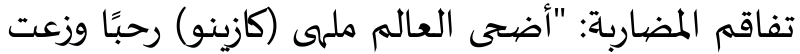

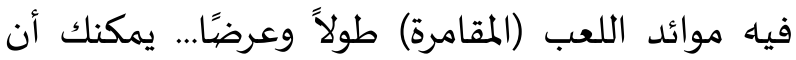

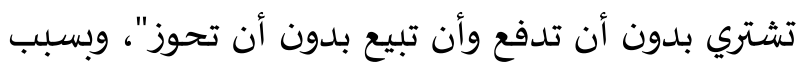
هذه المضاربة لم يكف القطاع المالي، ولن يكف عن تصلدير المشكلات إلى القطاع الحقيقي. 6-2: فقه الأسواق والمضاربة؛ غياب كلي للنظرفي المآلات برغم الشهادات المتقدمة ونظائرها التي لا يحصرها بحث كهذا، وبرغم شهادة واقع الحال؛ فإن فقه الأسواق
الشركة ترتب لمالكها حقًا في الريح، وتوجب عليه الخسارة

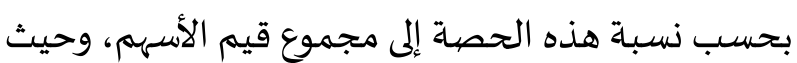

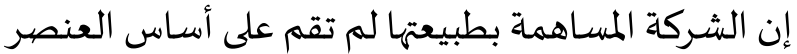
الشخصي في المساهم، إنما قامت على أساس وحدة مالية

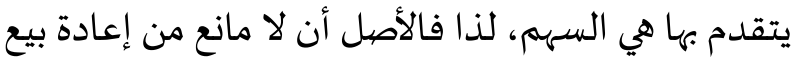
هذه الأسهم بما تمثله من حصص في سوق الأوراق المالية، وما يعنيه ذلك من حلول المشتري في المركز القانوني للبائع بكل ما يرتبه هذا المركز من مغانم أو مغارم.

وبهذا المعنى جاء في القرار الأول لمجلس المجمع الفقهي الإسلامي بمكة المكرمة حول سوق الأوراق المالية والبضائع: "أن العقود العاجلة على أسهم الشركات والمؤسسات حين تكون تلك الأسهم في ملك البائع جائزة شرعًا ..." (القرارات، 1398- 1424هـ 134)؛ إذ من المقرر فقهًا، جواز بيع

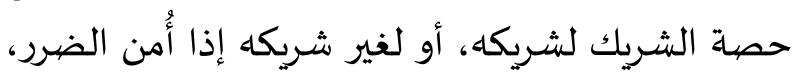

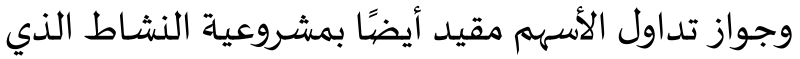
تمارسه الشركة التي أصدرتها، ثم هو مقيد بمراعاة حال المحل الذي تمثله؛ هذا ما تقرر فقهًا بصدد حكم تداول هال

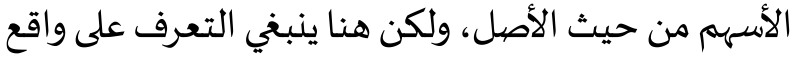
هذه الممارسة وآثارها وما يترجح القول به سياسةً.

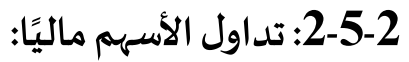
مكنت آليات التسهيم وإطلاق تداول الأسهم من استشراء المضاربات المالية. إن المضارب يهتم بأسعار الأسهه الآنية أكثر التراك

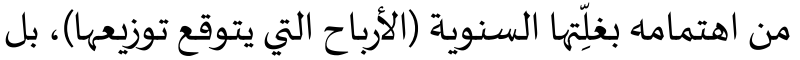
وأكثر من اهتمامه بما تكون عليه قيمتها على المدى البعيد، وهذا السلوك يترك آثارًا سلبية على كفاءة سوق رأس المال، وعلى الشركات المساهمة ذاتها إذ إن اشتغال حَمَلَة الأسهم المهر بمتابعة تقلبات الأسعار يضعف الشعور الانتمائي للمساهمين تجاه شركاتهم، ويكرس بقاء الإدارات غير الكُفُؤة بعيدًا عن المراقبة والمحاسبة (تاج الدين، 1405هـ 74-74) 
الوساطة غير المنتجاة، ويتعزز هذا التوجه،، بتواتر النهي عن بيع الطعام قبل قبضها كما ثبت في مصنفات الحديث، وهو نهي رأى ابن عباس أنه يعم جميع العروض (مالك، 1967م: 270). وما قرره حبر الأمة، ينطبق من باب أولى لى وأكد على الأسهم التي أتخذت متَّجرًا.

لقد توالت شهادات الواقع حول الآثار السلبية للمضاربة والتي لا أحسب أن الشرع يتسامح مع شيء منها. وإذا كان

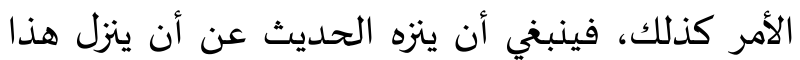

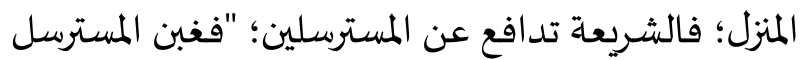
حرام" (الطبراني، 1404هـ 8، 126)، وتحتاط

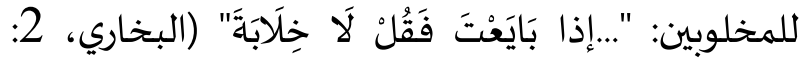

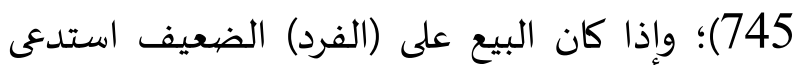
تشريعًا لحمايته، فكيف يكون الأمر مع الجمهور الضعيف (ذي الاستقراءات السطحية الذي يستغفله كبار المضاربين) ... ألا يستدعي وقفة لحمايته ؟!.

إن المضاربة سلوك تلبس بالمقامرة إلى حد كبير (أحمد، 1415هـ 488)، والموقف منها مسألة تتعلق بسياسة حكمية تقدر المصلحة العامة وتحتاط لها وليس فقط بأحكام فقهية افتراضية تقضي بإطلاق إجازة بيع المالك لحصته الشائعة. ترى؛ أليس في أحكام الشفعة التي قيدت إجازة تصرف بإناف الشريك بعدم لحوق الضرر بشريكه ما يسند الاحتراز من لحوق الضرر العام بالمجتمع حكمًا أو سياسـًً ؟!. لقد لاحظ تاج الدين (تاج الدين: 67، 83) أن الأسههم وهي محل العقد في المضاربات ليست سلعًا عادية، يحسن عموم المتعاملين التعرف عليها، الأمر الذي يقتضي وجود

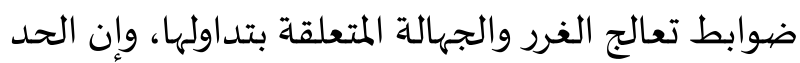
الأدنى من التقييد الذي لابد منه، يقضي بسـد الذرائع؛ وذلك بتسعير الأسهم من قبل خبراء محايدين على ضوء

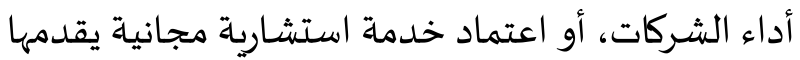

المالية الذي يركز اهتماماه في تصحيح مباني العقود المالية ويتغاضى بالكلية عن مآلاتها، يبدو أكثر تسامحًا مع المضاربة من الوضعيين أنفسهم؛ فقد اجتهد (أبو غدة، 2005م: 666ـ 669) في بيان محاسن المضاربة وفوائدها، وأشار أن ليس من قائل بتأبيد المشاركة وتقييد تداول الأسهم، كما دافع عن تمحض استهداف ما سماه ربحًا رأسماليًا بتعقب فروق الأسعار، ورأى في ذلك مصلحةً تتمثل في تحريك الأنشطة المختلفة، وأن ذلك مما ينطبق عليه الحديث: "دعوا الناس يرزق الله بعضههم من بعض"، وأن ما يُخشى وقوعاه من ضرر أو ما وقع فعلاً، مبعثه إهمال

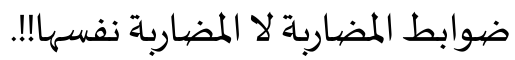

والذي أراه والله أعلم، أن الوصول إلى استنتاجات عريضية على هذا النحو الذي يسوّغ منطق الأسـواق المالية، ويضـي عليها المشروعية بعد كل ما تكشَّف من عبثيتها وأنانيتها، أمر في غاية الخطورة، وفيه افتئات على السياسة الشرعية الشئه التي ينبني أن تجتهد في صيانة المصلحة العامة، لا مصلحة المضاربين وصانعي السوق، ولا أحسب أن أحدًا يجحد مخاطر المضاربة، ولو التزمت بأحكام الربا وأحكام الديّن، ولو ابتعدت عن التضليل والإشاعات. أما حديث جابر رضي الله عناه وفيه: قال قال رسول

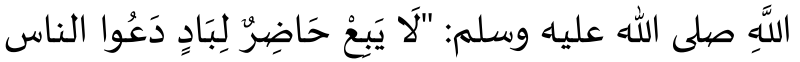

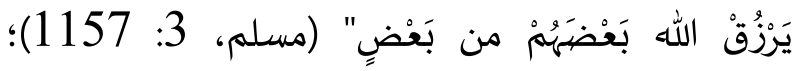

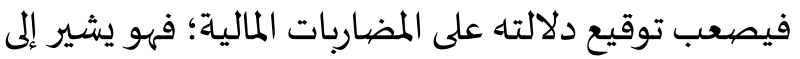
عمليات بيع حقيقية تظهر آثارها في محلات العقود وتحقق كل مقاصد البيوع، وترتبط بها فعاليات الاستهلاك والتجارة الحقيقية، وليس في المضياربة شيء من هذا؛ بل إن المتمعن في الحديث يجد فيه تأصيلاً لتوجه عام في التشريع الاقتصادي الإسلامي يمنح المضاربة، يتأكد ذلك بالنهي عن هذا النوع من السمسرة مع حِل جنس الوكالة، وباختزال 
(3)

\section{الهندسة المالية الإسلامية ومساراتها 1-3: في مفهوم الهندسة المالية وأهدافها}

الهندسة المالية عمومًا حقل من حقول المعرفة التطبيقية يهتم بابتكار أدوات وتطوير حلول لمشكلات التمويل. ولقد كانت عملية ابتكار الأدوات والحلول المالية تنتج عن تراكم المعرفة العملية ثم تتحول ابتداء إلى أعراف مالية مستقرة، ثم تتحول تاليًا إلى صيغ قانونية تعتمدها التشريعات المالية. ومع تطور الأسواق المالية تحولت الهندسة المالية إلى مهنة احترافية محددة يمتهنها متخصصون؛ ففي ثمانينيات القرن الماضي انتدبت (وول ستريت) أكاديميين وماليين

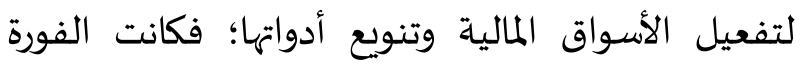

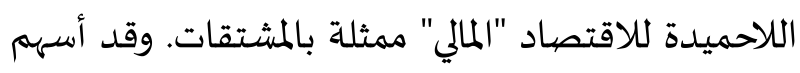
التطور في تقنيات الاتصال والمناخ الأيديولوجي المواتي لاستطالة نظام السوق في ترويج هذه المنتجات حول العالم.

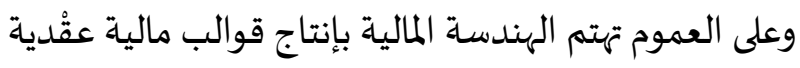

$$
\text { (حقوقية) منمَّطة وجاهزة تستهدف منها الآتي: }
$$

1. تحقيق المكاسب لصُّنّاع الأسواق والعاملين فيها.

2. تخفيض تكاليف الوساطة بين وحدات العجز ووحدات

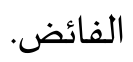

3. تعبئة الموارد المالية وتوسيع فرص المشاركة في النشاط

4. تأمين المرونة في إدارة الأصول تحقيقًا لمطلب الربحية

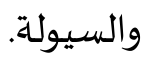

5. تأمين المرونة اللازمة لإدارة المخاطر تعزيزًا لمطلب التحوط والأمان.

وسنرى أن الهندسة المالية الإسلامية (التي كانت قد المداند سبقت اسمها المعاصر) كانت هي الأخرى معنية بابتكار
جهاز مختص لجمهور المتعاملين، وكلا الأمرين يعزز فكرة

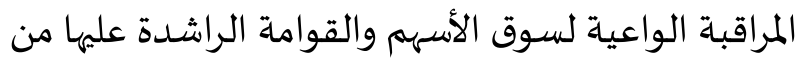

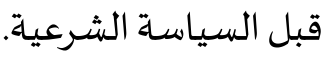

والخلاصة أن جواز بيع الحصة الشائعة فقيًا لا يعني

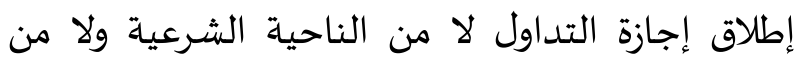

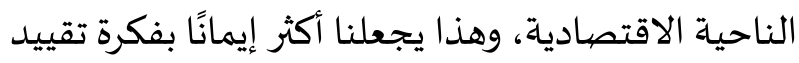

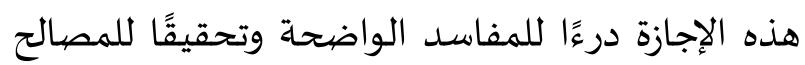
الراجحة، ومما يمكن أن يرد في هذا السياق:

(أ) السماح ببيعة واحدة للسهم في نهاية السنة المالية وبعد صدور بيانات الشركة. وهذه أفضل وسيلة للحد من المضاربة وللتقريب بين القيمة السوقية والقيمة (العادلة). (ب) اشتراط مرور مدة زمنية معينة بين موعد شراء

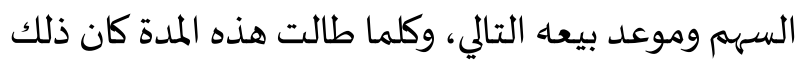
أدعى للاقتراب من القيمة العادلة. (ج) تحميل السهم برسم تداول تصاعدي يتناسب مع عدد المرات التي يباع بها يعمم ريعه لصالح المجتمع. إن الحقيقة التي يجب أن لا ننساها ولا تلفتنا عنها

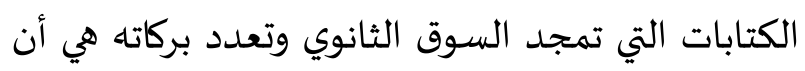
النشاط المضاربي نشاط طفيلي عقيم لا يضيف قيمة إلى لئي

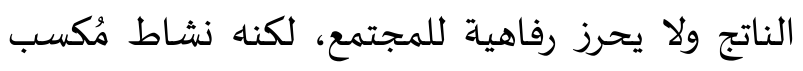

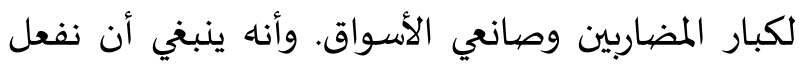
أحكام المعاملات للحد من هذا النشاط؛ فلا نشتري دون

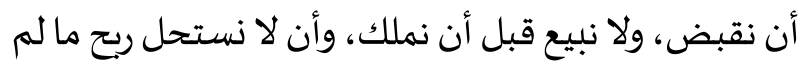
نضمن. يجب أن تتذكر هندستنا المالية جيدًا توجيه النبي

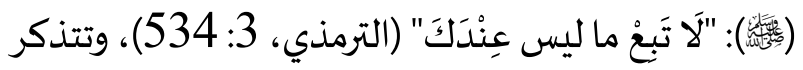

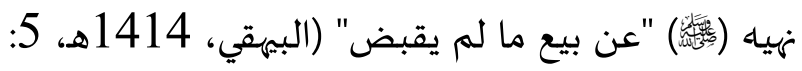

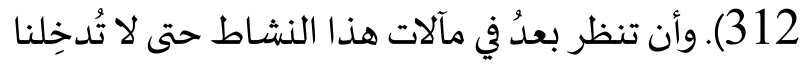
جحر الضَّبّ الذي دخله الآخرون وعلقوا فيه!!. 
الطريق إلى ذلك المحرَّم ... والمحتال يريد أن يتوسل إليه. ولهذا لما اعتبر الشارع في البيع والصرف والنكاح وغيرها

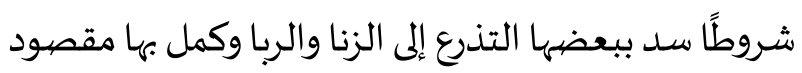

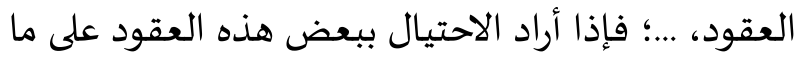

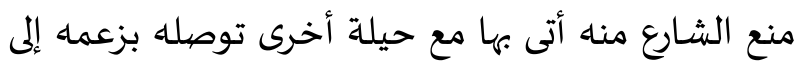
نفس ذلك الشيء الذي سد الشارع ذريعته فلا يبقى لتلك الك التها

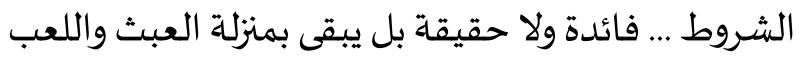
وتطويل الطريق إلى المقصود" (ابن تيمية، د.ت. 3: 265). ويقول ابن القيم: "... فأين من يمنع الجائز خشية الوقوع في المحرَّم إلى من يعمل الحيلة في التوصل إليه ئ ل..

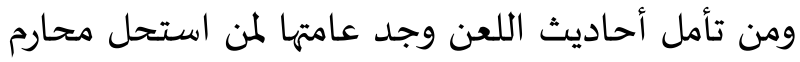

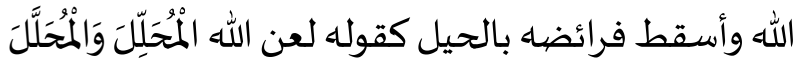

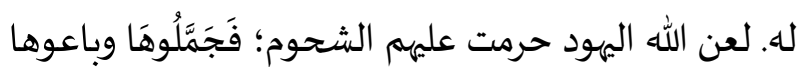

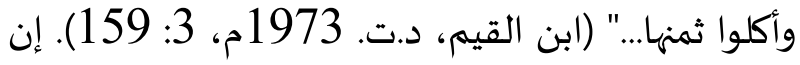

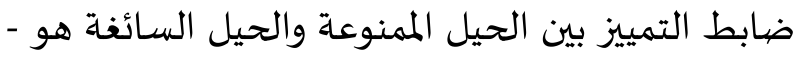
والله أعلم - اندفاع العلة؛ فإن اندفعت العلة التي لأجلها

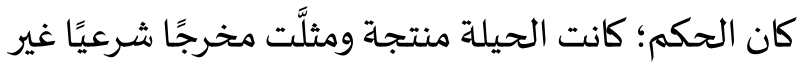
مقدوح فياه، وإلا فهي تمويه وتعمية تضمى إلى فساد المعاملة الميلة

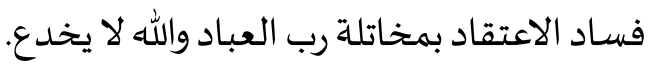
(ب) التذرع بالشروط لنقض مقتضيات العقود في التفاف واضح على مقاصيد الشارع مسايرة لنوازع العاقدين

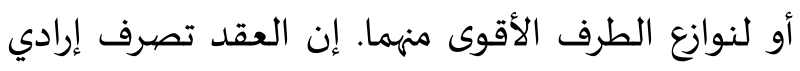

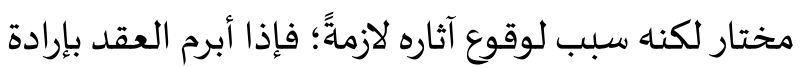

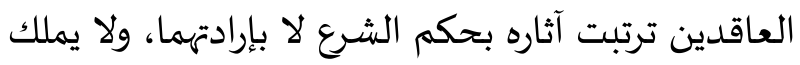
العاقدان تعطيلها؛ فالسبب (العقد) من المكلف والحكم

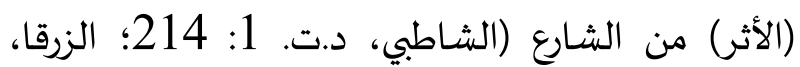

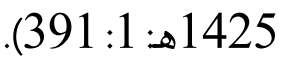

إن ما قضت به العقود لا ينبغي أن تعطله الشروط،

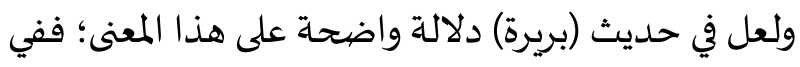

الأدوات وإيجاد الحلول المالية؛ يقول (العنزي، 1436هـ.

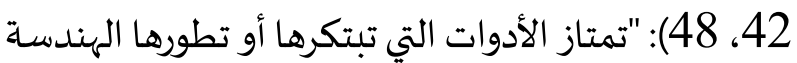

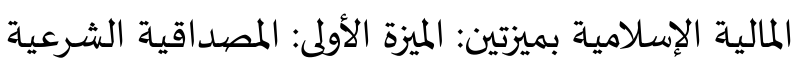
... (و)الميزة الثانية: الكفاءة الاقتصادية"، وعقد مبحثًا للفروق بين الهندسة المالية الإسلامية والهندسة المالية التقليدية ذكر فيه: أن الانضباط في الأولى أكبر من الثانية

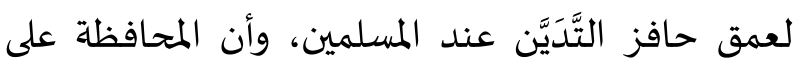
الأحكام الشرعية أيسر من المحافظة على الأحكام الوضعية لكمال الأولى وقصيور الثانية. والحق أن ما ذكره الباحث يعكس نظرة معيارية تلخص ما ينبغي أن يكون عليه حال الهندسة المالية الإسلامية وليس نعتًا تقريريًا لحالها الكائن

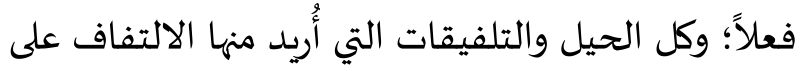
الأحكام الشرعية قديمًا وحديثًا، وصريح الموقف منها، المداء تقتضي تقييد كلام الباحث وصرفه نحو مسارها الإيجابي حصرًا. إذ سنرى أن الهندسة المالية الإسلامية قد اتخذت التهايد مساريين مختلفين كما يتضح من الآتي. 2-3: الهندسة المالية الإسلامية ومسارها السلبي كانت الهندسة المالية الإسلامية واقعًا مستحثة بالبحث عن مخارج للمعاملات من الأحكام الناهية؛ وهذه الحقيقة

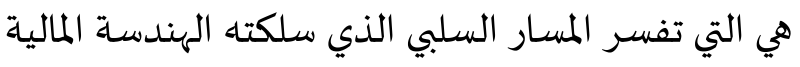
الإسلامية القديمة والمعاصرة. ولعل أبرز مظاهر هذا

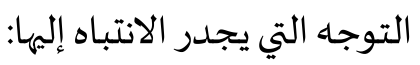

(أ) اللجوء إلى الصورية والاحتيال مثل التذرع بمبنى عقد البيع لتمرير المداينة الربوية كما في بيع العينة. وحقيقة الحيل: "تقديم عمل ظاهر الجواز لإبطال حكم شرعي... فمآل العمل فهها خرم قواعد الشريعة" (الشاطبي، د.ت. 4: 201). جاء في الفتاوى الكبرى: "التذرع إلى المحرمات بالاحتيال أولى أن يكون حرامًا ... وأعلم أن تجويز الحيل

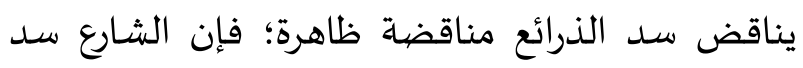


(ج) التذرع بالوعود: ومن المظاهر السلبية في الهندسة المالية "الإسلامية" المعاصرة إيرادها الوعود على ما كان

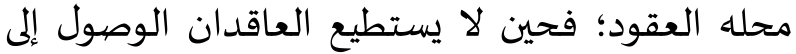
مقاصدهما بالعقود ولا بالشروط لمخالفتها مقتضيات العقود خاصة المسماة منها؛ فإنهما يتحولان إلى الوعود التي

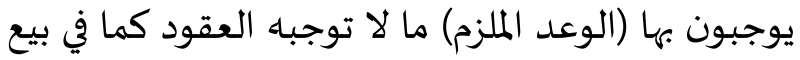
المواصفة والمواعدة على الصرف.

(د) تطويع البيوع والمشاركات والإجارات لتكون محض كضات وسائل لإثبات مداينات صفرية المخاطرة كما هو حال البيوع والإجارات التمويلية والمشاركات المنتهيية بالتمليك؛ فأحكام كل من هذه العقود المركبة تفترق عن أحكام العقود الأصلية ومقاصدها.

(هـ) ومن العقود التي جنح إليها كثير من الممولين والمتمولين عقود التورق والتورق المعاكس الذي يكون فيه المصرف الإسلامي متمولاً، والتورق الدوار الذي يجهز آلية تسدد بها المديونية السابقة بمديونية تورقية لاحقة، وكل تطبيقات التورق المصرفي كانت محل اعتراض النظر الفقهي الجاد كما بدأ من قرار مجمع الفقه الإسلامي الدولي رقم 179 (19/5)، بشأن التورق: (الفقهي المعروف والمصرفي المنظم،1430هـ).

(و) السعي إلى استدفاع مخاطر الاستثمار والتجارة

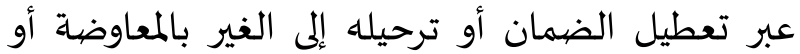

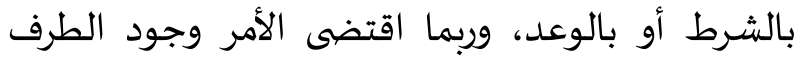
الثالث المتبرع بالضمان لمقصد لا يجهله قريب من السوق

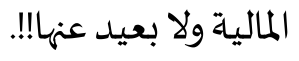

3-3:3 الهندسة المالية الإسلامية ومسارها الإيجابي

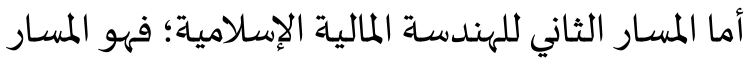
الإيجابي الذي يتحقق فيه الغرض المالي مع المصداقية
الصحيحين أن أم المؤمنين عائشة رضي الله عنها أرادت أن

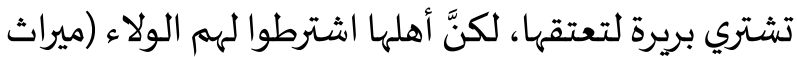

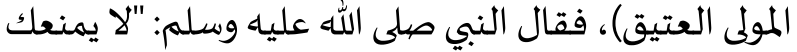
ذلك فإنما الولاء لمن أعتق" (البخاري، 2: 760). وفي رواية الإمام مسلم قال مخاطبًَا السيدة عائشَّة: "ابْتَاعِي فَأَعْتِقِي

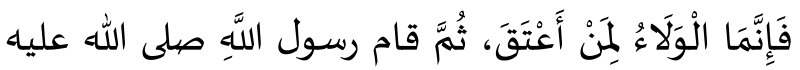

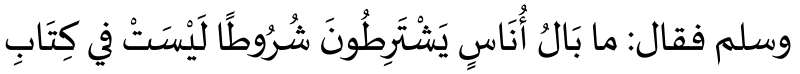

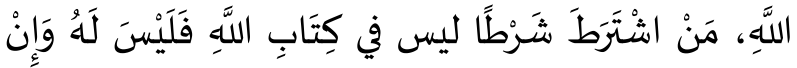

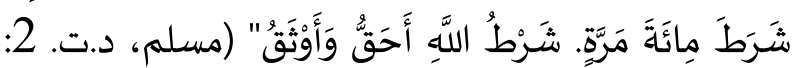

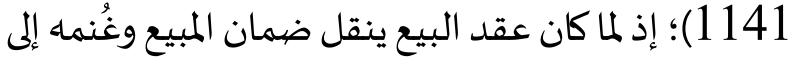
المشتري حكمًا فلا يجوز تغيير شيء من هذه الآثار أو تعطيلها باشتراطات العاقدين. وهنا ينبني التمييز بين شروط العقد والشروط فيه: أما شروط العقد فهي ما يشترطه الشرع في المعاملات والعقود، مثل شروط الانعقاد التي تقتضي توفر الأهلية المعرفية

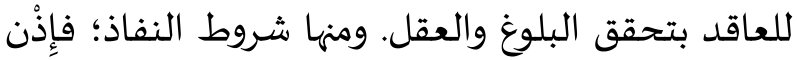

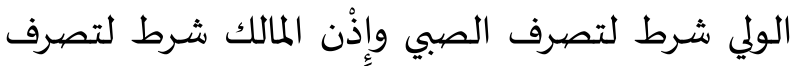
الفضولي، ومنها شروط الصحة بسلامة محل العقد من الخبث والغرر، ومنها شرط اللزوم بنفي الخيار. وكل ما تقدم شروط لها أصولها الشرعية وهي ليست موضوع كلامنا هنا، أما الشروط في العقد فهي شروط جُعْلية مصدرها إرادة العاقدين. وتقسم هذه الشروط إلى: شروط توكيدية وشروط توثيقية وشروط تبيينية وشروط تعويضية، وكل ذلك يمكن قبوله إذا لم يتعارض مع جوهر العقد ومقتضاه، لكن الشروط التقييدية هي مظنة المحذور لأهها تستهدف تغيير آثار العقد التي ثبتت شرعًا بتواضع من العاقدين، وما لم يكن الشارع قد أذن بهذا القيد فلا يمكن الدفاع عن مشروعيته. 
6) عقود توثيقات غايتها توثيق الديون ثبوتًا واستئداءً مثل الرهن والكفالة والحوالة.

7) عقود استحفاظات غايتها حفظ المال عند الغير بعوض ألاض مثل عقد الاستحفاظ بالأجرة، أو الاستحفاظ أمانة

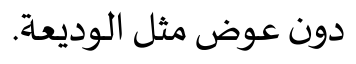

8) العقود غير المسماة وهي عقود لم يرد لها اسم محدد في

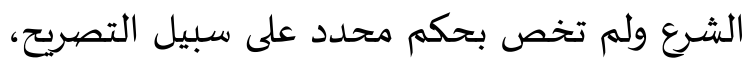

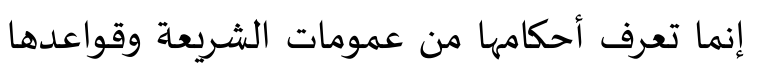
(الزرقا، 1425هـ 1: 632، 635). ومثلها العقود المركبة وهي منظومات متكاملة تضرم عقودًا وشروطًا ووعودًا تشكل بمجموعها وارتباطها وحدة عقدية واحدة غير قابلة للتجزئة.

لقد استطاعت الهندسة المالية الإسلامية الصحيحة،

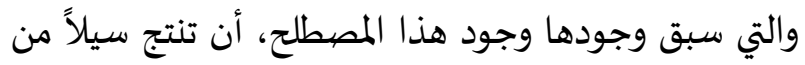
الحلول الفعّالة والمشروعة في عوالم التمويل والتجارة الحقيقية، قبل أن تزاد عليها منتجات وأدوات أخرى جديدة

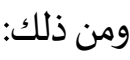

الكتابة والإشهاد والرهن لحل مشكلات التوثيق الذي

$$
\text { يستلزمه الائتمان والتجارة. }
$$

ل شركات الأموال المختلفة برسومها القديمة والحادثة (مثل شركة العنان المفاوضة والمساهمة) لتحل مشكلة المانة

$$
\text { الحاجة إلى حجوم التمويل الكبيرة. }
$$

"عقد المضاربة ليحل مشكلة الحاجة المتبادلة بين العمل والمال، وليوحد بينهما في إطار عقدي تحقيقًا لمصالح العاقدين ومصالح الهيئة الاجتماعية من بعد.

عقد البيع الذي ارتضاه المولى تعالى أسلوبًا لانتقال الأعواض استجابة لحاجات المتبادلين إلى الأعيان والأثمان بعيدًا عن الغصب والنهب، ويسّجل للإسلام الإن الإنيان
الشرعية وفيه تندرج شبكة عريضة من العقود والمنتجات

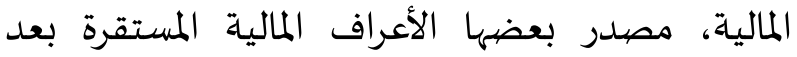
تمحيصها وتنقيتها، وبعضها الآخر جاء ابتكارًا خالصًا متميزًا للنظام المالي الإسلامي الذي قام على الأسس والمبادئ العقدية التي وضعها الشارع لتحكم حركة المال بين الناس الماس الماسي وترك للمؤمنين بهديه في أمصارهم وأعصارهم المختلفة

$$
\text { اختيار الوسائل والأدوات المناسبة. }
$$

ولقد حفل الفقه الإسلامي بمنظومة واسعة من العقود كلها تستهدف ضبط المعاملات المالية على أسس المبادئ الشرعية والمقاصد المرعية، ومن ذلك:

1) عقود تمليكات غايتها تمليك المال للغير بعوض مثل البيع والإجارة، ومنها ما هو تمليك بغير عوض مثل تمانل

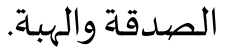

2) عقود إسقاطات غايتها إسقاط حق للمكلف في ذمة الآخر ومن هذه الإسقاطات ما يكون بعوض مثل العفو عن القصاص نظير العوض المالي وكذا الخلع. ومنها ما

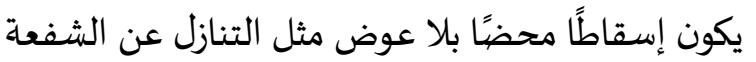
وإبراء ذمة المدين بحط الدين عنه كليًا أو جزئيًا. 3) عقود مشاركات غايتها ضم الأموال أو الأعمال إلى بعضها بهدف التنمية والريح ومن ذلك شركات الأموال وشركات الأعمال ومن ذلك أيضًا عقود المضاربة. 4) عقود إطلاقات غايتها تفويض الغير في تصرف هو تلون ممنوع منه في الأصل، مثل التوكيلات التي تطلق يد الوكيل في التصرف فيما وكل به، والإذن للصببي المميز في التجارة، والإذن للمحجور عليه في التصرف. 5) عقود تقييدات غايتها تقييد من أطلقت يده في التصرف ابتداءً مثل عزل الوكلاءوعزل الأوصياءوالنظّار. 
(المحال) والمكلف (المحال عليه) أو المسحوب عليه. ومثال ما تقدم ما تعامل به عبد الله وأخوه مصعب رضي الله عنهما من رقاع وصكوك. هذا ويلاحظ أن هذه ماحه الأدوات المالية تناظر البكرات في عالم الفيزياء الحركية ووظيفتها توفير المرونة الكافية للتعامل مع الالتزامات ضمن القواعد العامة للمعاملات لجهة ضبط ذمات الالتزام أو تاريخها أو مكان إبرائه. ح تنقيد المبادلات لإخراج المتعاملين من صعوبات المقايضاة وقيودها ومن دائرة ربا الفضل كما في حديث

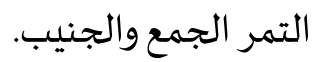

ل الترخيص في العرايا في خمسـة أوسق أو ما دون خمسـة أوسق، كما ثبت في الصحيح عند النهي عن المزابنة ترفقًا للحاجة، مع تعذر التيقن من العلم بالمماثلة. ل الكوبونات الأجرية أو صكوك الطعام التي اعتمدتها الدولة الإسلامية إذ كانت تخصص لموظفيها العموميين: أجورهم معرَّفة بكميات معلومة من صنوف معلومة من الطعام دفعًا لمشكلة نقص السيولة. ل ومن الحلول المالية التي عرفها الفقه الإسلامي مما يندرج في باب الحيل المشروعاة، حل محمد بن الحسن الذي وافقه ابن القيم، لمشكلة نكول المواصف بأن يشترط الموعود عند شرائه المبيع على مالكه خيارًا يمكنه من رد المبيع إن نكل الواعد خلافًا لما ذهب إليه التنظير الفقهي المعاصر الذي أقر إلزامية الوعد. ل ومن الحلول المالية العملية التي تبنتها المصارف الإسلامية، ما كان يفعله الزبير (ِّئيَّ) إذ كان يقبل المال من الناس على أنها قرض لا وديعة تحقيقًا لمشروعية الضيمان ولمشروعية الربح الذي يتولد عن التصرف فيه.
اهتمامه بضبط هذا العقد على نحو معجز تقصر

$$
\text { عنده كل التشريعات الوضيعية. }
$$

ل البيع الآجل والبيع منجَّم الثمن لحل مشكلة نقص

$$
\text { السيولة لدى المشتري. }
$$

\ بيع السَّلَمَ ليحل مشكلات تمولية وتسويقية للبائع وذلك بتعجيل الثمن وتأجيل المثمن. وتاليًا جاء السَّلَم الموازي ليؤمن كفاءة اعتماد السَّلَم كصيخة استثمارية. ح قبولها لمبدأ تسهيم رأس المال (تجزئته) لحل مشكلات حجوم التمويل الكبيرة بتبنيها آلية التسهيم أو التصكيك أو التوريق أو التقطيط، والقط هو النصيب: "وَقََالُوا رَبَّنَا

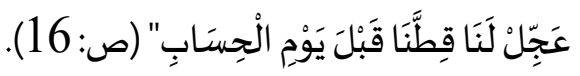
ح قبولها لمبدأ التداول في الأسواق المالية بالضوابط التي تحكم مبانيه ومآلاته لحل مشكلات السيولة. $\checkmark$ تحويل جهاة الالتزام وتحويل مكان إبرائه بالحوالات وبالسفاتج وبالكمبيالات؛ فالدين في الإسلام علاقة مالية لا شخصية، ومن أحيل على مليء فليتبع. ح الوكالة التي تقيم الوكيل الملتزم محل الأصيل الذي يوكله في الحدود التي يرتضيانها في ما أقره الشارع. ل الكفالة التي تضهم ذمة الغير الخالية من الالتزام إلى ذمة

$$
\text { الملتزم تعضيدًا لها وتدعيمًا للمعاملات المالية. }
$$

ل رقاع الصيارفة أو السندات الإذنية، التي توثق إقرارًا

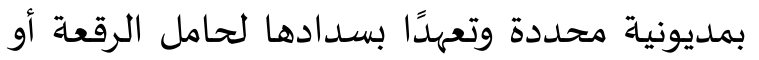
السند، في تنميط لعلاقة ثنائية بين الدائن (حامل الرقعة أو السند) والمدين (محررها). ل الصك أو ما صار يعرف اليوم بالشيك، وهو أمر من المالك إلى المستودَع بدفع مبلغ للمستفيد، في تنميط

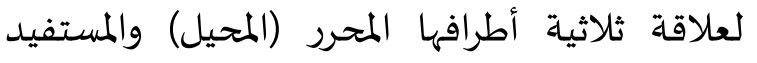


$\checkmark$ ح البطاقات المصرفية كوسيلة للدفح، أو للاقتراض والدفع،

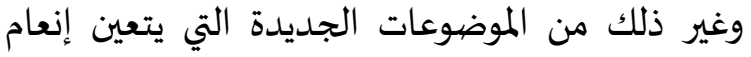
النظر فهيا لاستبيان حكمها أولاً وعمليتها ثانيًا.

وعلى العموم يمكن القول إن الهندسة المالية الإسلامية

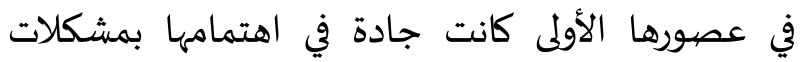
التمويل والتجارة العملية، أما الهندسة المالية المعاصرة

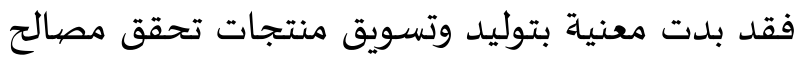
صُنَّاع السوق والمضاربين والناشطين في الاقتصاد المالي

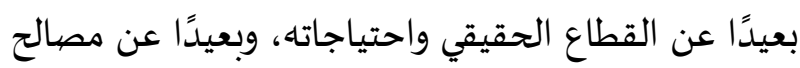

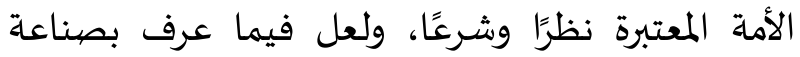

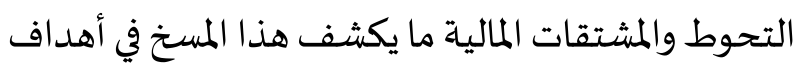
الهندسة المالية وفي مخرجاتها كما يتضح جليًا في الفقرة

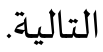

\section{4-3: الهندسة المالية وصناعة التحوط}

يقصد بالتحوط اتقاء المخاطر وتخفيف آثارها، وحين يكون الحديث عن الاستثمار؛ فإن المخاطر تتلخص في:

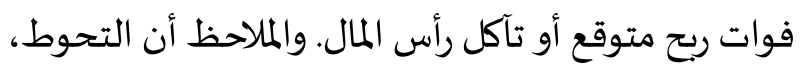
وهو هدف من أهداف الهندسة المالية التقليدية المعاصرة، قد طنى على أهدافها الأخرى حتى أصبحت وكأنها معنية فقط بالبحث عن حلول افتراضية للتحوط كان أبرزها

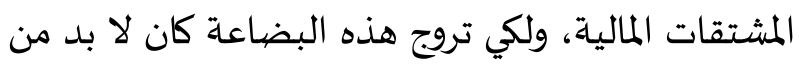
تصنيع الحاجة إليها بالدعاية والإعلان، وبإذكاء الخوف

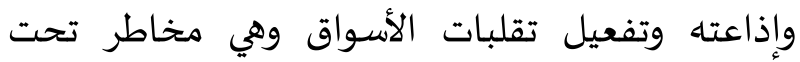
السيطرة تلجئ المتعاملين إلى التحوط!! وهكذا انصرف الاهتمام في الريع الأخير من القرن الماضي وبجدية عجيبة إلى استحداث سيل من المنتجات التي تحتمل الغرض التحوطي وتُسوَّق تحت شعاره، لكنها واقعيًا متجهة للغرض المضاربي، وذلك عبر تصنيع الغرر

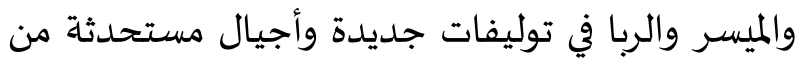

ل واستحدث الحنفية عقد الاستصناع وأفردوه عن السَّلَم وخصوه بشروط وقيود تحقيقًا لمقاصد إنتاجية وتمويلية. ل نشرت الهندسة المالية الإسلامية المعاصرة مروحة من

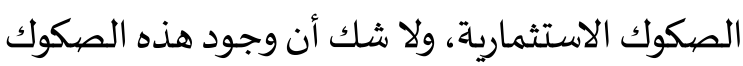
بشرط سلامة إصدارها وتداولها يخفض المخاطر بتنويع الأصول ويسر إدارة السيولة. ح ومن النظم المستحدثة التي تبنتها الهندسة المالية الإسلامية، عقود الإجارات والمشاركات التمويلية المنتهية بالتمليك، وهي منظومات عقدية وشرطية مركبة ينبغي تمحيصها قبل البت بمشروعيتها وهو ما كان للقرارات المجمعية والمعايير الشرعية فيه نظر وتفصيل. ` ومن الحلول المقترحة في الهندسة المالية المعاصرة التعديل الذي اقترحه (السويلم: د.ت. 18) على بيع المرابحة للآمر بالشراء، وذلك بدخول المصرف شريًا للتاجر في ملكية المراية بضاعة تُعَدُّ للبيع مرابحة، فيتولى التاجر إدارتها تخرئنًا

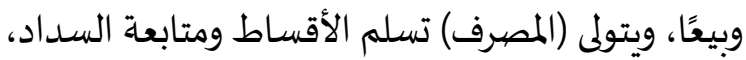
وبذلك يتخفف المصرف من إجراءات القبض والتسليم ويكون شريكًا للتاجر لا منافسًا له. ل ومن هذه النماذج مقترح (عطية، 1409ه: 111-

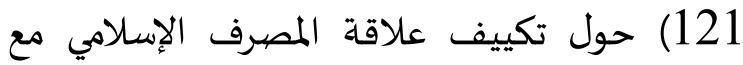
أصحاب الحسابات الاستثمارية على أساس الوكالة المأجورة بدلاً من اعتباره مضاربًا مشتركًا. ل نظام النُّمَر (الأعداد) الذي يمزج وحدات المال بوحدات

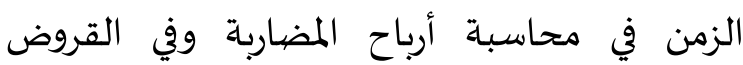

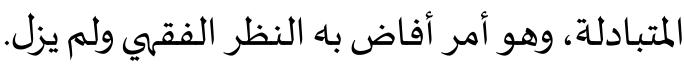
القروض المتبادلة حلاً لمشكلة السيولة لتعذر الاستفادة

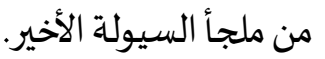


من الفراغ القانوني ولا تخضع لأي تشريعات وطنية أو دولية، ومسوّغِ مشروعيتها المتفلتة على هذا النحو: أنها تخدم الاقتصيادات المضيّفة!!!.

وهنا كان ينبغي للهندسة المالية الإسلامية الواعية الأمينة أن تحرر معنى المخاطرة وتحدد موقف أحكام المعاملات منها، ومناه ندرك الخطأ الذي وقعت فياه عندما دعت إلى وأد المخاطرة بالمعنى الإيجابي كموقف شجاع ملتزم يلج باه المستثمر غيب الاستثمار الضروري للمجتمع راضيًا بقدره، وسعت إلى تحجيمها أو ترحيلها إلى الغير

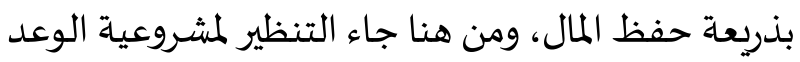
الملزم في بيوع المواصفة ولمشروعية التأمين التجاري ولمشروعية الخيارات والمستقبليات كأساليب لإدارة المخاطر المصرفية والاستثمارية، وهو تنظير في غاية العقم والخطورة على الصعيدين المالي والشرعي. وقد جاء الواقع مبرهنًا على سلامة المبادئ المالية الإسلامية الأصيلة؛ فما إن بدأت الأزمة تعصف بالأسواق المالية وباقتصادات العالم في 2008م حتى اكتشف المتحوطون بالمشتقات المالية وبصناديق التحوط، الحقيقة المُرَّة وأدركوا أنهم كانوا في مسعاهم التحوطي كمثل العنكبوت اتخذت بيتًا، وإن أوهن البيوت لبيت العنكبوت لو كانوا يعلمون.

لقد بني النظام المالي التقليدي المعاصر على عقيدة فاسدة ماليًا قبل أن تكون فاسدة شرعيًا، ومن وجوه فسادها السعي إلى فك الارتباط بين مغانم الاستثمار ومغارماه (مخاطره)، ومن وجوه فسادها سماحها بنقل المخاطر إلى الغير عبر عقود ووعود يتوافق عليها العاقدون عبر أدوات مالية كثيرة، ونسوا أن المخاطر محكومة بقانون ربما له دقة قوانين الفيزياء، فهي تلد مع الاستثمار ولا تموت إلا بموته، وكان على النظام الذي شرَّع تلك الأنانية
منتجات مالية مزعومة لا تعدو أن تكون تشقيقات جديدة لذاك الثالوث القديم بأسماء جديدة: بيوع خيارات وعقود مستقبليات ومبادلات ...إلخ. وقد انزلقت الهندسة المالية الإسلامية أو كادت أن تنزلق إلى منزلق الهندسة المالية التقليدية، وكان المدخل المهل الساذج لهذا التوجه هو التوكيد على موقف الإسلام الصحيح من المال ووجوب حفظه وصيانتا،، لتصل إلى استنتاج سريع وخطير يتلخص في أن التحوط من المخاطر بواسطة المشتقات أمر سائغ بل واجب، لأناه وسيلة لبلوغ يلون

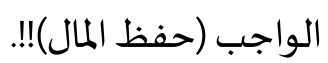

ومع هكذا تصور؛ كان لا بد من السعي إلى تأهيل المشتقات فقهًا؛ وهكذا وبقدر بادٍ من التكلف تم تخريج عقود الخيارات على بيع العربون أو على خيار الشرط، كما تم تخريج المستقبليات على عقود السَّلَم والاستصناع، كل ذلك دون التوقف عند القضية الأساسية؛ أعني ماهية المخاطرة التي يسوغ شرعًا التحوط منها، أو التي يجوز ترحيلها إلى الغير ليخلص لنا الغنم والخراج والربح بعيدًا عن ملازماتها، وكأننا لم نسمع شيئًا عن استحقاق الغنم بالغرم عملاً بقول النبي صلى الله عليه وسلم: "الْخَرَاجُ بِالضَّمَانِ" (أبو داود، 3: 284) وبنهيهاه صلى الله عليه وسلم عن ربح ما لم يضيمن (البيهي، 5: 348). نعم لقد أسـدلت الهندسة المالية المعاصرة الستار على الما لهار هذه الأسس الحاكمة للتمويل الإسلامي لصالح القول بحفظ المال وتنميته بما تتيحه الأسواق المالية من أدوات التحوط وآلياته، وانساق كثير من المسلمين المسترسلين وراء مشورة أئمة التحوط؛ فركبوا قطار الهندسة المالية التقليدية متحوطين ومضاربين!!، واستدرج السمان منهم إلى مصائد المخفلين أو ما كان يسوَّق على أنه صناديق تحوط، وهي أوعية مالية انتقائية عملاقة تنشط في حيز 
ولا ينبغي أن يفهم من كلامنا أننا نستهدف المخاطر أو الخسائر، ولا ينبغي أن يفهم من كلامنا تسفيه الشعور

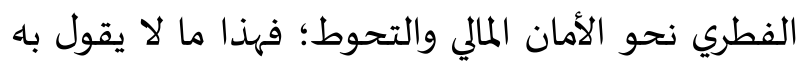

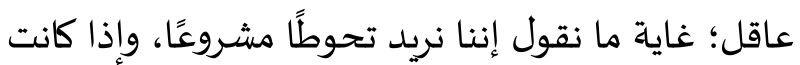
نظرية العقد تسوّغ للأغيار كل ما يتراضون عليه، فإن نظرية العقد الإسلامية تشترط أن يكون ذلك في دائرة الإباحة التي حددت تخومها أحكام الشريعة.

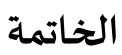

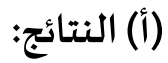
• إن غالب النظر الفقهي المعاصر يتركز في مباني

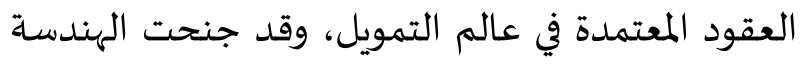
المالية بهذا النظر في أحيان كثيرة إلى الصهورية والاحتيال؛ فأحالت بذلك البيوع المطلقة إلى بيوع تمويلية، وأحالت المشاركات والإجارات إلى عجلات يتمحض دورها في تمرير الماتير المداينات، وكأننا لم نسمع بقاعدة العبرة للمقاصد والمعاني

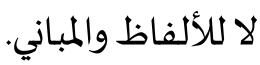

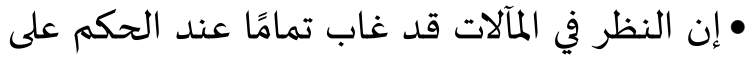
مشروعية المعاملات؛ ففي الوقت الذي يدعى فيه القضاء

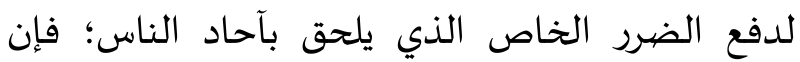

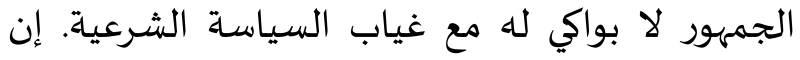

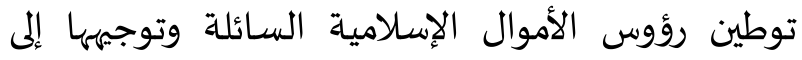

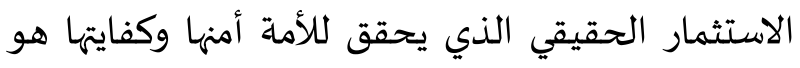

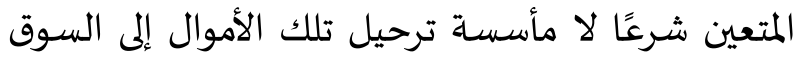

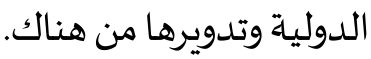

• إن ضبط الأسواق ضرورة شرعية وضرورة اقتصادية؛

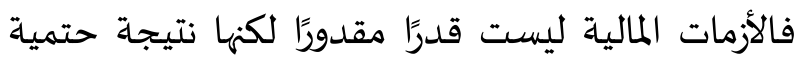
للانفلات في عمل المؤسسات الخاصية وطغيان الاقتصياد الرمزي؛ فكل عمليات المضاربة والتوريق وتبايع الديون والمقامرات تمارس في الأسواق بعيدًا عن أي قوامة اجتماعية،
وذلك الدجل المالي أن يتحمل غُصَّة تلك الأصهول السامة التي تتشردق بها البنوك وشركات التأمين والمؤسسات المالية والتي تتكلف الحكومات ومن ورائها دافعو الضرائب أعباءها الهائلة بينما انسحب اللصوص والنصابلابون إلى الى كهوفهم يستمرئون التنعم بوافر جنهيم تاركين العالم

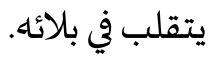

والمطلوب من الهندسة المالية الإسلامية وقفة نقدية تخرجها من مدار الهندسة المالية التقليدية خاصة وأن القوم صاروا يتلفتون إلى الإسلام ونظامه المالي والاقتصادي، ...،

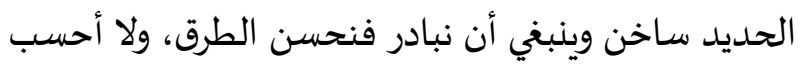
أن من الحكمة في شيء أن نؤجل الدعوة إلى النظام المالي

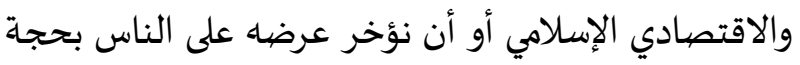

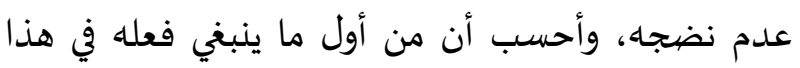

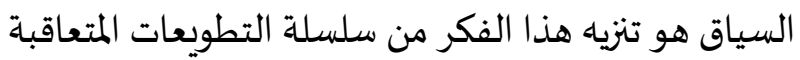
التي قربته من الفكر التقليدي حتى لا يُفجع المتطلعون إليه

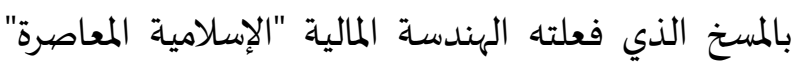
مسايرة للأسواق المالية والمصرفية التقليدية أو تأثرًا بها. إن مزية النظام المالي الإسلامي تكمن في أمرين: • الأول هو توسيع قاعدة المخاطرة وعدالة اقتسامها بإشراك الممول مع المستثمر في المغانم والمغارم. • أما الثاني فهو الشجاعة في قبول المخاطرة الضرورية

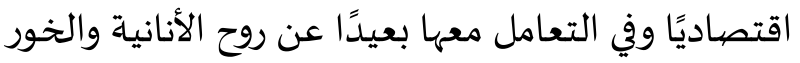

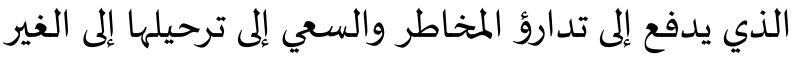
بحق وبغير حق. إن غياب هذه الشجاعة والموقف الملتزم أسس لتجارة طفيلية واسعة هي تجارة الغرر (التأمين)، وهي تجارة إن أفلحت حينًا في إنقاذ بعض مؤسسات النظام المالي فإنها لم تفلح في إنقاذ هذا النظام برمته بل إنل ربما كانت سببًا في انهياره. 
• إن وسطية اقتصاد الأمة "الوسط" والشهادة على الناس (وسطية الاقتصاد الإسلامي) تحتم ضرورة الضبط الوظيفي لنشاط الأسواق بما يعيدها إلى وظائفها الضرورية

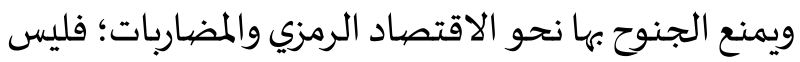

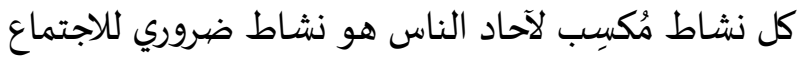
الإنساني. إن تضخم الصناعة المالية المعاصرة ما عاد سمنة

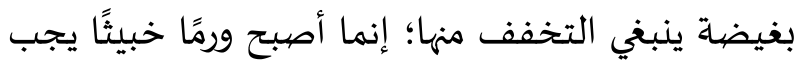

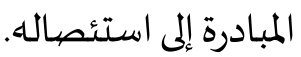

• ضرورة التمييز بين نطاق عمل لجان الرقابة الشرعية

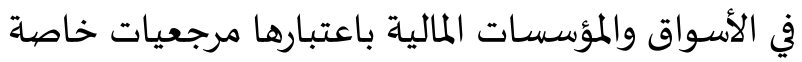
معنية بالبت في سلامة مباني العقود، ومرجعية الأمة:

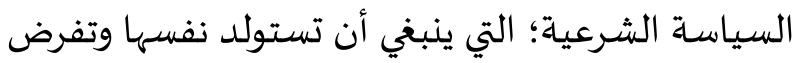
قوامتها على اللجان الخاصة وتستكمل النظر في سلامة النتائج التي يؤول إلهيا حال الناس كشرط كاف لمشروعية نشاط تلك الأسواق والمؤسسات المالية. •ولعل أهم ما ينبغي أن تهتم به السياسة الشرعية هو

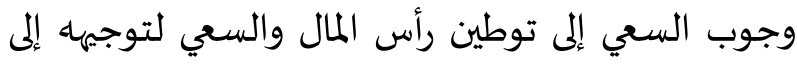
الاستثمار في الاقتصاد الحقيقي الذي به ترتهن كفاية الأمة وبه يرتهن أمنها. وهذا يستدعي إعادة النظر في نشاط التهاد المؤسسات المالية التي تُسْهم في ترحيل رؤوس الأموال إلى إلى

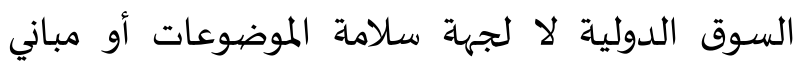
العقود التي تتعامل هذه المؤسسات بها فقط؛ بل لجهية

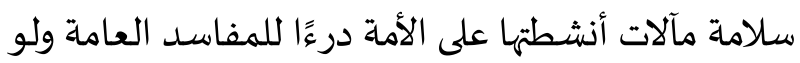
تعارضت مع المصالح الخاصة للمنتفعين منها.
وبقدر ما يسمح المجتمع ب"تحرير" هذه الأسواق عليه أن

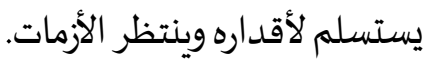

• إن الذي استحث النظر الفقهي المعاصر للجان الرقابة الشرعية وهيمن عليه في مجال الأسواق والمؤسسات المالية، هو منطق البحث عن مخارج فقهية لأنشطة تلك المؤسسات التي لم تشأ أن تذهب بعيدًا عن المنطق السائد في الأسواق

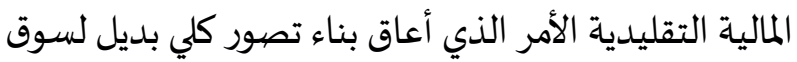
مالي إسلامي وظيفي وغيب فيه دور السياسة الشرعية.

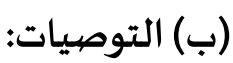

• إن الأدب مع الله تعالى يحتم على المعنيين بالهندسة المالية الإقلاع عن المنطق السائد في التعامل مع الأحكام

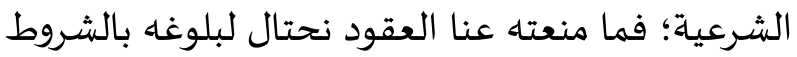

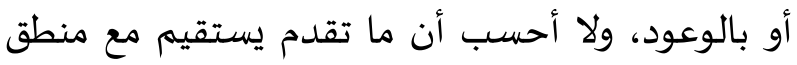
الإيمان، ولنتذكر جميعًا أن المريض الذي يخاتل طبيبه (ولله المثل الأعلى) إنما يخون مصلحتاه، لنرجم الشيطان

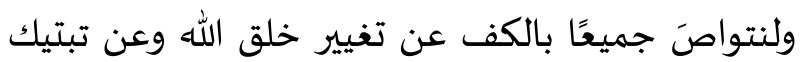

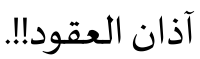

•ضرورة النظر في المآلات عند تقدير أنشطة الأسواق والمؤسسات المالية في إطار سياسة شرعية حازمة وراشدة

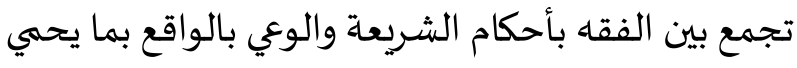
الأمة ومصالحها من الاجتهادات النسبية ومن طغيان

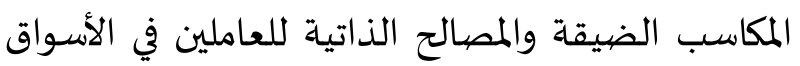
والمؤسسات المالية. ولا شك أن تقييد المباح هو المتعين شرعًا دفعًا للمفاسد العامة واستجلابًا للمصالح العامة. 


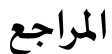

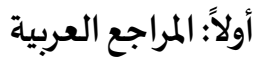

أبوغدة، عبدالستار (2005م): "صناديق الاستثمار الإسلامية؛

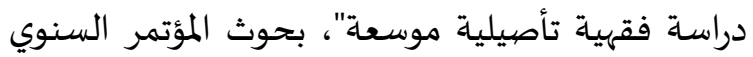
الرابع عشر، كلية الشريعة والقانون، جامعة الإمارات

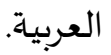

أحمد، أحمد مجي الدين (1415هـ/1995م): أسواق الأوراق

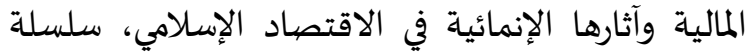

$$
\text { صالح كامل للرسائل الجامعية. }
$$

آليه، موريس (1413هـ/1993م): الشروط النقدية لاقتصاد

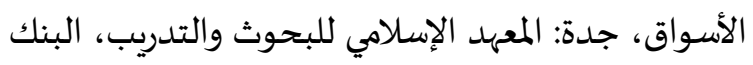

$$
\text { الإسلامي للتنمية. }
$$

الإمام مالك (1967م): موطأ الإمام مالك برواية محمد بن

$$
\text { الحسن الشيباني، القاهرة، لجنة إحياء التراث الإسلامي. }
$$

البخاري، محمد بن إسماعيل (1407هـ/1987م): الجامع الصحيح المختصر، تحقيق: مصطفى ديب البغا، بيروت:

$$
\text { دار ابن كثير، الطبعة الثالثة. }
$$

بني عامر، زاهرة (2017م): تجربة الصكوك الإسلامية؛ دراسة وتقويم، أطروحة دكتوراه بقسم الاقتصاد والمصارف لجربه

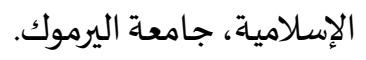

البيهقي، أحمد بن الحسين بن علي بن موسى (1414هـ/

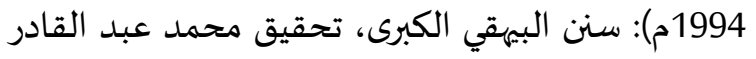
عطا، مكة المكرمة: مكتبة دار الباز. تاج الدين، سيف الدين إبراهيم (1405هـ/1985م): "نحو نموذج إسلامي لسوق الأسهم"، مجلة أبحاث الاقتصياد

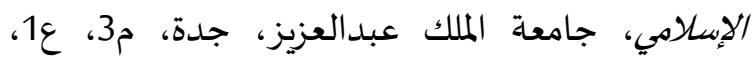
ص ص: ص1-61الترمذي، محمد بن عيسى أبو عيسى (د.ت.): سنن الترهني، تحقيق أحمد محمد شاكر ...، بيروت: دار إحياء التراث العربي. ابن العربي، أبو بكر محمدد بن عبدالله (د.ت.):أحكام القرآن، المران، تحقيق محمد عبد القادر عطا، بيروت: دار الفكر. ابن القيم، محممد بن أبي بكربن أيوب بن سعد الزرعي الدمشقي

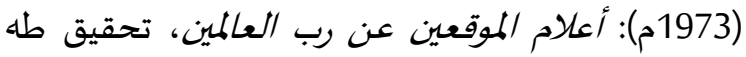
عبدالرؤوف سعد، بيروت: دار الجيل. ابن تيمية، تقي الدين أحمد بن عبد الحليم الحر اني (د.ت.): الفتاوى الكبرى، تحقيق حسنين محمد مخلوف، بيروت:

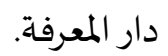

ابن تيمية، تقي الدين أحمد بن عبد الحليم الحر اني (د.ت.):

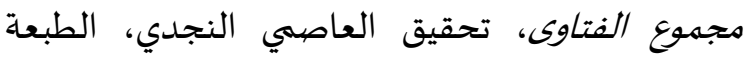
الثانية، الرياض: مكتبة ابن تيمية. ابن حبان، محمد بن حبان التميي البستي (1414هـ/1993م): صحيح /بن حبان، تحقيق شعيب الأرناؤوط، الطبعة مئد الثانية، بيروت: مؤسسة الرسالة. ابن حجر، أحمد بن علي بن حجر العسقلاني (د.ت): فتح الباري شرح صحيح البخاري، تحقيق محب الدين الخطيب، بيروت: دار المعرفة. ابن عابدين، محمد أمين (1421هـ): حاشية رد المختار على الدر المختار:شسح تنوير الأبصار، بيروت: دار الفكر. ابن عبدالبر، يوسف بن عبدالله (1387هـ): التههيل، تحقيق العلوي والبكري، المغرب: وزارة الأوقاف والشؤون

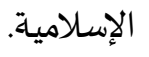
ابن مفلح، أبو إسحاق إبراهيم بن محمد الحنبلي (1400هـ): المبدع في شرح المقنع، بيروت: المكتب الإسلامي. أبو داود، سليمان بن الأشعث السجستاني الأزدي (د.ت.): سنن أبي داود، تحقيق محمد محيي الدين عبد الحميد،

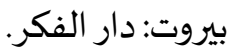


عطية، جمال الدين (1409هـ/ 1989م): المشاركة المتتالية في

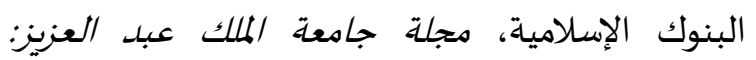

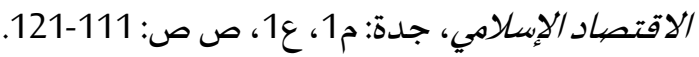
العنزي، مرضي بن مشوح (1436هـ/2015م): فقه الهندسة المالية الإسلامية، الرياض: كنوز أشبيلية. العياشي، زرزار (1436هـ/2015م): ضرورة إنشاء سوق للأوراق المالية الإسلامية؛ تجربة سوق رأس المال المال الإسلامي في

$$
\text { ماليزيا، مجلة بيت المشـورة، ع3. }
$$

القرطبي، أبو عبدالله محمد بن أحمد الأنصاري (د.ت):

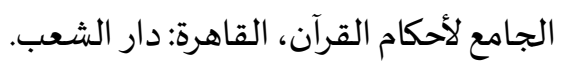

القره داغي، علي (19-23 محرم 1432هـ/2010م): إدارة السيولة في المؤسسات المالية الإسلامية، المجمع الفقهي الإسلامي/رابطة العالم الإسلامي، الدورة (20). القري، محمد علي (10-11نوفمبر، 2014م): تطبيق الملكية النفعية والملكية القانونية في التمويل الإسلامي الدولي، المؤتمر العلمي التاسع لعلماء الشريعة، كوالالمبور، ماليزيا: الأكاديمية العالمية للبحوث الشرعية (إسرا). القطان، عبدالستار (اكتوبر، 2004م): البدائل المشروعة

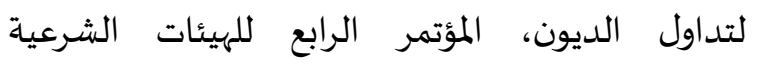
للمؤسسات المالية الإسلامية، البحرين. القفال، أبو بكر محمد الشاشي (1988م): حلية العلماء في معرفة مذاهب الفقهاء، تحقيق ياسين درادكة، عمان:

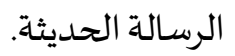
الكاساني، علاء الدين (1982م): بدائع الصنائع، بيروت: دار

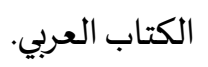

لال الدين، أكرم وبوهراوة، سعيد (19-23 محرم 1432هـ/

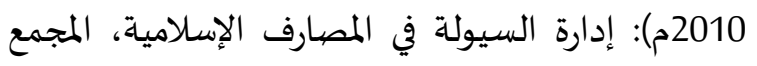
الفقهي الإسلامي/رابطة العالم الإسلامي، الدورة (20).
حسان، حسين حامد (2003م): صكوك الاستثمار، هيئة المحاسبة والمراجعة للمؤسسات المالية الإسلامية. حيدر، علي (د.ت): درر الحكام: شرح مجلة الأحكام، تحقيق المحامي فهي الحسيني، بيروت: دار الكتب العلمية. الدسوقي، محمد عرفه (د.ت): حاشية الدسوقي على الشرح الكبير، تحقيق محمد عليش، بيروت: دار الفكر.

الدمياطي، أبو بكر ابن السيد محمد شطا (د.ت): حاشية إعانة الطالبين، بيروت: دار الفكر. الزرقا، مصطفى أحمد (1425هـ/ 2004م): المدخل الفقهي العام، الطبعة الثانية، دمشق: دار القلم. زيتوني، عبدالقادر وناصر، سليمان (يونيو2012م): التصكيك الإسلامي كآلية لإدارة السيولة في المصارف الإسلامية، مجلة إسرا الدولية للمالية الإسلامية، م3عاعـ، كوالالامبور: الأكاديمية العالمية للعلوم الشرعية. السمرقندي، علاء الدين (1984م): تحفة الفقهاء، بيروت: دار الكتب العلمية.

السويلم، سامي (د.ت.): صناعة الهندسة المالية؛ نظرات في المنهج الإسلامي، شركة الراجي المصرفية للاستثمار،

$$
\text { الكويت: بيت المشورة للتدريب. }
$$

الشاطبي، إبراهيم بن موسى اللخمي الغرناطي المالكي (د.ت): الموافقات في أصول الفقه، تحقيق عبد الله دراز، بيروت:

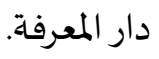

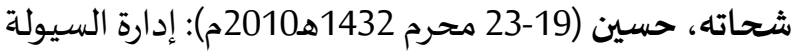
في المصارف الإسلامية؛ المعايير والأدوات، المجمع الفقهي الإسلامي/رابطة العالم الإسلامي، الدورة (20). الطبر اني، سليمان بن أحمد بن أيوب (1404هـ / 1983م): المعجم الكبير ، تحقيق حمدي عبدالمجيد، الموصل: مكتبة المبل

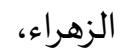




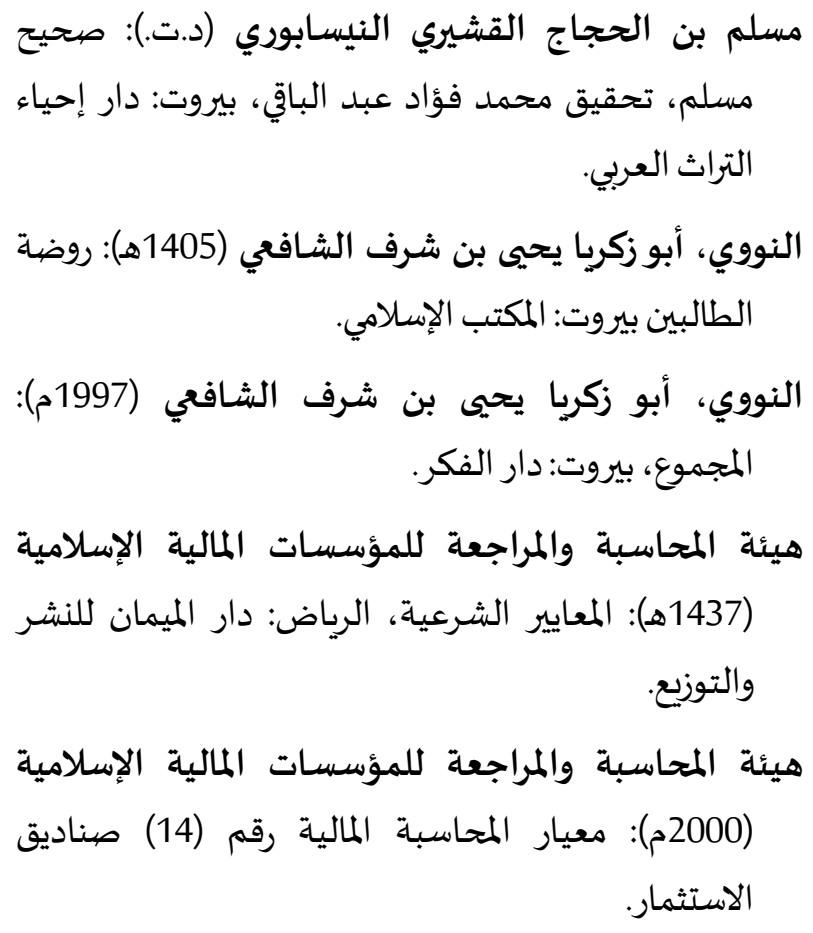

Keynes, J.M. (1973) The General Theory of Employment, Interest and Money, U.K: Macmillan.

\section{Translation of Arabic References}

Abu Dawud, Sulayman Ibn al-Ash'ath al-Sijistani alAzdi (N.D): Sunan Abi Dawood, Tahqiq: Muhammad Mohieddin Abdulhamid, Beirut: Dar al-Fikr.

Abu Goudda, Abdulsattar (2005g): "Islamic Investment Funds; an Extensive Jurisprudence Study", Proceedings of the Fourteenth Annual Conference, College of Sharia and Law, UAE University.

Accounting and Auditing Organization for Islamic Financial Institutions (1437h): Shariah Standards, alRiyadh, Dar Al- Maiman Publishing and Distribution.

Accounting and Auditing Organization for Islamic Financial Institutions (2000g): Financial Accounting Standard No. (14): Investment Funds.

Ahmed, Mohieddin (1995g): Stock Markets and their Development Impacts in the Islamic Economy, Saleh Kamel Series of University Thesis.

Al-Ayashi, Zerzar (1436h/2015g): The Need to Establish an Islamic Stock Market; the experience of the Islamic capital market in Malaysia, Bayt al-Mashora Journal, No, 13.

$$
\begin{aligned}
& \text { الماوردي، علي بن محمد بن حبيب البصري (1419هـ): الحاوي } \\
& \text { الكبير، تحقيق علي معوض وعادل عبدالموجود، بيروت: }
\end{aligned}
$$

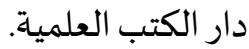

$$
\begin{aligned}
& \text { مجمع الفقه الإسلامي الدولي (1408هـ/ 1988م)، الدورة } \\
& \text { الرابعة، جدة، قرار رقم: } 30 \text { (4/3) بشأن سندات المقارضية الماتها } \\
& \text { وسندات الاستثمار. } \\
& \text { مجمع الفقه الإسلامي الدولي (1430هـ/2009م)، الدورة }
\end{aligned}
$$

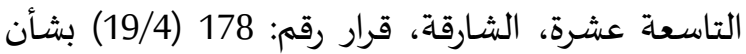

$$
\begin{aligned}
& \text { الصكوك الإسلامية/القرار رقم } 179 \text { (19/5) بشأن التورق. } \\
& \text { مجمع الفقه الإسلامي الدولي (1433هـ/2012م)، الدورة } \\
& \text { العشرين، وهران، القرار } 188 \text { (3/20)، بشأن استكمال } \\
& \text { موضوع الصكوك الإسلامية. } \\
& \text { المجمع الفقهي الإسلامي (1398-1424هـ/1977-2004م): } \\
& \text { قرارات المجمع الفقهي الإسلامي، رابطة العالم الإسلامي الإسي الإهي } \\
& \text { بمكة المكرمة، القرارات من الأول إلى الثاني بعد المائة. } \\
& \text { ثانيًا: المراجع الأجنبية }
\end{aligned}
$$

Al-Bayhaqi, Ahmed ibn al-Hussein ibn Ali ibn Musa (1414h/ 1994g): Sunan al-Bayhaqi al-Kubra, Tahqiq: Muhammad Abdulqader Atta, Makkah: Maktabat Dar al-Baz.

Al-Bukhari, Muhammad ibn Ismail (1407h/1987g): alJamie al-Sahih al-Mukhtasir, Tahqiq: Mustafa Deeb Al-Buga, Beirut: Dar ibn Katheer, 3rd ed.

Al-Dessouki, Mohamed Arfa (N.D): Hashiat aldessouki ala al-Sharah al-Kabir,Tahqiq Muhammed Aliash, Beirut: Dar al-Fikr.

Al-Dumayati, Abu Bakr ibn al-Sayyid Muhammad Shata (N.D): Hashiat 'iieanat al-ttalibin, Beirut: Dar al-Fikr.

Al-Enezi, Mishri ibn Mashouh (1436h/ 2015g): Faqah Alhindasat Almaliat al'iislamia, Riyadh: Kunuz 'Iishbilia.

Al-Imam Malik (1967g): Mu'ta 'al-Imam Malik, narrated by Muhammad ibn al-Hasan al-Shaibani, Cairo, lajnat 'iihya' alturath al'iislamii. 
Al-Kasani, Ala'eddin (1982g): Badi' al-Sona', Beirut: Dar al-Kitab al-Arabi.

Allais, Maurice (1993g): Monetary Conditions for the Market Economy, Jeddah: Islamic Research and Training Institute, Islamic Development Bank.

Al-Maawardi, Ali ibn Mohamed ibn Habib al-Basri (1419h): Al-Hawi al-Kabir, Tahqiq Ali Moawad \& Adel Abdulmawjud, Beirut: Dar alkutub al-eilmia.

Al-Mjme' al-Faqahi al-'Iislamiu (1398-1424h /19772004g): Qararat Al-Mjme' al-Faqahi al-'Iislamiu, Rabitat alealam al'iislamii bi Makah al-Mukramati (No. 1-102).

Al-Nawawi, Abu Zakaria Yahya ibn Sharaf al-Shafei (1405 h): Rawdat al-Taalibayn, Beirut: al-Maktab al'Iislami.

Al-Nawawi, Abu Zakaria Yahya ibn Sharaf Al-Shafei (1997g): al-Majmueu, Beirut: Dar Al-Fikr.

Alqaffal, Abu Bakr Muhammad Al-Shashi (1988g): Hilyat Alulama' fi Maerifat Madhahib Alfuqaha', Yaseen Daradkeh, Amman: Dat Alrisalat Alhadithah.

Al-Qura Daghi, Ali (19-23 Muharram 1432h/ 2010g): Liquidity Management in Islamic Financial Institutions, Almjme' Alfuqhiu Al'Iislamiu / Islamic World League, Session (20).

Al-Qurtubi, Abu Abdullah Muhammad ibn Ahmad alAnsari (N.D): Aljami'e Li'ahkam Al-Quran, Cairo: Dar alsha'b.

Al-Samarqandi, Alaeddin (1984h): Tuhfatu al-Fuqaha', Beirut: Dar al-Kuttab al-elmiyya.

Al-Shatibi, Ibrahim ibn Musa al-Lakhmi al-Garnati (N.D): Al-Muafaqat fi 'Usul al-Fqih, Tahqiq: Abdullah Daraz, Beirut: Dar al-Ma'refah.

Al-Suwailem, Sami (N.D): Financial Engineering Industry: An Islamic Approach, Al Rajhi Banking Investment Company, Kuwait: Al-Mashora Training House.

Al-Tabarani, Sulaiman ibn Ahmad ibn Ayoub (1404h/ 1983g): Almo'jam Alkabir, Hamdi Abdulmajeed, Mosul: Alzahra Library.

Al-Tirmidhi, Muhammad ibn Issa (N.D): Sunan alTirmidhi, Tahqiq:, Ahmed Mohammed Shaker and others., Beirut: Dar 'iihya' alturath alarabi.

Al-Zarqa, Mustafa Ahmed (1425h/2004g): al-Madkhal al-Faqhi al-aam, 2nd ed, Damascus: Dar Al-Qalam.

Attia, Jamal al-Din (1409h/ 1989g): The Successive Participation in Islamic banks, Journal of King Abdul Aziz University: Islamic Economics, Jeddah, Vol.1, No. 1, pp. 111-121.
Beni Amer, Zahra (2017g): Experience of Islamic Sukuk; study and evaluation, $\mathrm{PhD}$ thesis, Department of Islamic Economics and Banking, Yarmouk University.

El-Ghari, Mohamed Ali (10-11 November, 2014g): Application of Utilitarian, Legal Ownership in the International Islamic Finance, 9th Scientific Conference of Shari'a Scholars, Kuala Lumpur, Malaysia: International Academy of Shari'ah Research (ISRA).

Haidar, Ali (N.D): Durar al-Hukkam: Sharah Majalat al'ahkami, Tahqiq: Fahami al-husayni, Beirut: Dar alkutub al-eilmia.

Hassan, Hussein Hamid (2003): Investment Sukuk, Accounting and Auditing Organization for Islamic Financial Institutions.

Ibn Aabidin, Muhamad 'Amin (1421h): Hashiat Rad Almukhtar Aalaa Aldur Almukhtar Sharah Tanwir Al'absar, Beirut: Dar al-Fikr.

Ibn Abdulbarr, Yusuf ibn Abdullh (1387h): Al-Tamhid, Tahqiq: al-Alawi \& Bakri, Morocco: the Ministry of the General Endowments and Islamic Affairs.

Ibn al-Arabi, Abu Bakr Muhammad ibn Abdullah (N.D): Ahkam Alquran, Tahqiq: Mohammed Abdulqader Atta, Beirut: Dar al-Fikr.

Ibn al-Qayyim, Muhammad ibn Abi Bakr ibn Ayyub ibn Sa'ad al-Zara'i al-Dimashqi (1973g): A'alam Almuaqiein Ean Rab Ala'lamin, Tahqiq: Taha Abdulraouf Saad, Beirut: Dar al-Jil.

Ibn Hajar, Ahmad ibn Ali al-Askalani (N.D): Fath alBari: Sharh Saheeh al-Bukhari, Tahqiq: Muhib alDeen al-Khatib, Beirut: Dar al-Maarifah.

Ibn Hibban, Muhammad ibn Hibban al-Tamimi alBasti (1414h/ 1993g): Saheeh Ibn Habban, Tahqiq Shu'ayb al-Arnaout, 2nd ed, Beirut, Muasasat Alrisala.

Ibn Mufleh, Abu Ishaq Ibrahim al-Hanbali (1400h): AlMubdi' fi sharah al-Muqn', Beirut: Islamic Office.

Ibn Taymiyyah, Taqial-Din Ahmad ibn Abdulhalim alHarani (N.D): Alfatawaa Alkubraa, Tahqiq: Hassanein Muhammad Makhlouf, Beirut: Dar alMaarifah.

Ibn Taymiyyah, Taqial-Din Ahmad ibn Abdulhalim alHarani (N.D): Majmue Alfatawaa, Tahqiq: al-Aasmi al-Najdi, 2nd ed, Riyadh: Maktabat ibn Taymiyyah.

International Islamic Fiqh Academy (1408h/ 1988g), Session 4, Jeddah, Qarar raqm: 30 (3/4) bishan Sanadat al-Muqaradat wa Sanadat al-Istithmar. 
International Islamic Fiqh Academy (1430h/ 2009g), Session 19, al-Shaariqah, Qarar raqm: 178 (4/19) bishan al-Sukuk al'iislamia/ Qarar raqm 179 (5/19) bishan al-Twrq.

International Islamic Fiqh Academy (1433h/ 2012g), Wahran, Session 20, Qarar raqm: 188 (20/3) bishan aistikmal mawdue al -Sukuk al'iislamiah.

Laluddin, Akram \& BoHarawah, Said (19-23 Muharram 1432h/ 2010g): Liquidity Management in Islamic Banks, Almjme' Alfuqhiu Al'Iislamiu/ Islamic World League, Session (20).

Musallim ibn al-Hajjaj al-Qayshiri al-Nisabouri (N.D): Saheeh Muslim, Tahqiq: Mohamed Fouad Abdelbaqi, Beirut: Dar 'iihya' alturath al'Arabii.

Qattan, Abdul Sattar (October, 2004h): Legal Alternatives for Debt Handling, 4th Conference of
Shari'ah Boards of Islamic Financial Institutions, Bahrain.

Shehata, Hussain (19-23 Muharram 1432h/ 2010g): Liquidity Management in Islamic Banks; Standards and Tools, Almjme' Alfuqhiu Al'Iislamiu / Muslim World League, Session (20).

Taj al-Din, Saif al-Din Ibrahim (1405h/ 1985g): "Towards an Islamic model of the stock market", Islamic Economics Research Journal, Jeddah, Vol.3, No.1.

Zeitouni, Abdelkader \& Nasser, Sulaiman (June 2012): Islamic Sukuk as an Instrument for Liquidity Management in Islamic Banks, ISRA International Islamic Finance Journal, Vol. 3, No.1, Kuala Lumpur: International Academy of Islamic Sciences. 
عبدالجبار حمد عبيد السبهاني: من مواليد حديثة/ الأنبار/ العراق/ 1957م، دخل كلية الإدارة

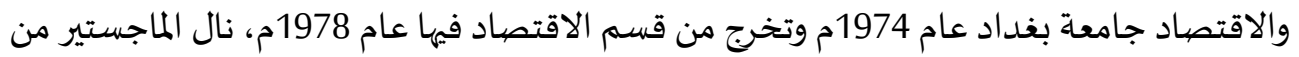

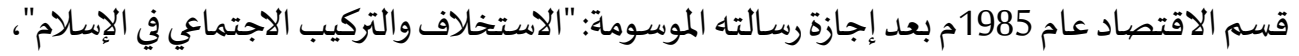

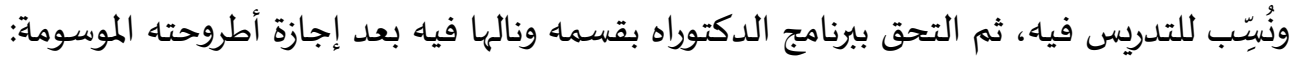

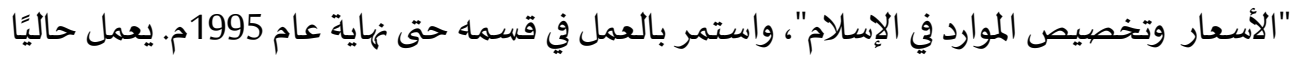

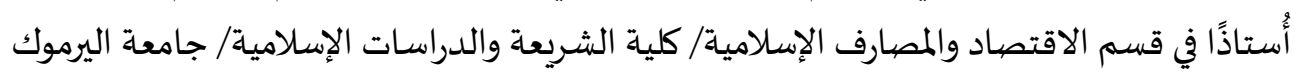

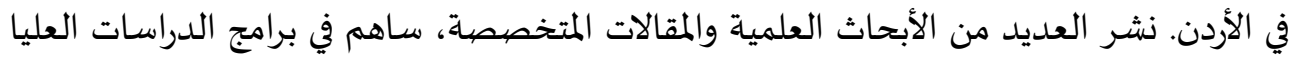

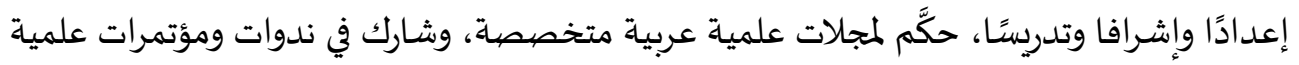

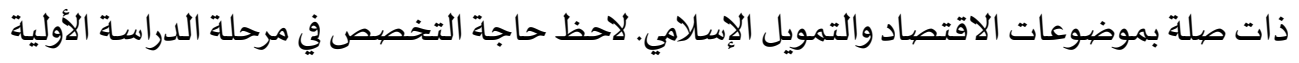

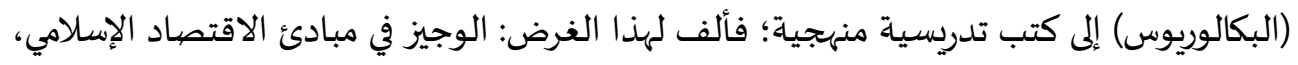

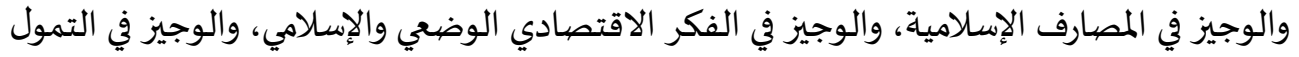

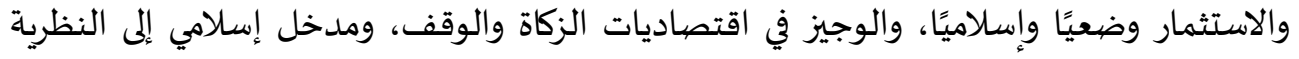

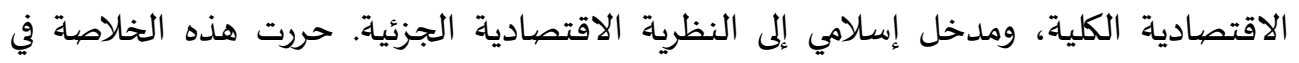
2019/6/9 2. البريد الإلكتروني: sabhany@gmail.com.

http://al-sabhany.com

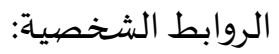
https://faculty.yu.edu.jo/Sabhany/SitePages/Home.aspx https://scholar.google.com/citations?hl=ar\&user=Ve27fFUAAAAJ 


\title{
Revision in the Jurisprudence of Markets and Financial Engineering
}

\author{
Abduljabbar Hamad Obaid Al-Sabhany \\ Department of Islamic Economics and Banking \\ Faculty of Al-Sharee'a and Islamic Studies/ Yarmouk University, Jordan
}

\begin{abstract}
Financial markets, alongside with commercial banks, have been the most important financial intermediaries in different societies. Muslim communities must, by virtue of their faith, abide by Shari'a controls in their financial markets and in all their transactions. This paper reveals institutional shortcomings and a lack of social guardianship that caused a complete omission of the final results and effects while evaluating the activity of the financial markets. Moreover, the paper identified a clear trend towards formalism stamping the path of Islamic financial engineering in its effort looking for solutions and exits for transactions by resorting to the terms and promises. In the End, The paper concluded on many recommendations based on its main conclusions considering the state of the contemporary markets in light of the recent American financial crisis (2007-2008).
\end{abstract}

KEYWORDS: Financial Markets, Islamic Financial Engineering, Transaction controls, Beneficial Ownership, Speculation.

JEL CLASSIFICATION: B590, G010, G190

KAUJIE CLASSIFICATION: C3, C59, K1 